\title{
WOMEN AND THE SQUANDER CYCLE IN FOOD WASTE IN THE UNITED KINGDOM: AN ECOFEMINIST AND FEMINIST ECONOMICS ANALYSIS
}

\author{
Martina Topić, Audra Diers Lawson and Sarah Kelsey
}

\author{
Leeds Business School, Leeds Beckett University \\ 562 Rose Bowl, Portland Crescent \\ LS1 3HB, Leeds, West Yorkshire, United Kingdom \\ e-mail: M.Topic@leedsbeckett.ac.uk
}

\begin{abstract}
This paper examines the interconnections between gender, class, food security, sustainable food waste, and values. We link feminist economics and ecofeminism in the context of grocery shopping in the United Kingdom. As an environmental and economic issue, food waste is emerging as a global threat, with developed nations grossly contributing to the squander cycle of resources. Such contextualization allows us to both explore the feminist economics perspective, as well as examine routine decision-making by placing it within the larger value system, and connecting it with the sustainability and environmental protection debates. Data were collected on a purchased Smart Survey sample of a UK-wide population, using an approximately 20-minute online questionnaire. A data set of 792 complete responses was included in the analysis. The findings present a dual narrative on grocery shopping. Reduced-priced shopping is often evaluated by women as socially responsible and environmentally friendly. However, women from lower socioeconomic backgrounds demonstrate a resentment towards price-reduced shopping and evaluate it negatively. We argue that these different attitudes reflect relative perceptions of agency and control, which the data suggest are connected to the propensity for food waste and a worsening of the squander cycle.
\end{abstract}

Keywords: women, ecofeminism, feminist economics, yellow-sticker shopping, squander cycle, UK

\section{INTRODUCTION ${ }^{1}$}

Globally speaking, the issues surrounding food security and sustainable economies are often intertwined and linked with women, women's incomes, and women's values regardless of whether we are discussing women in developing or developed nations (Belahasen et al., 2018; Dangour, 2018; Garcia and Wanner, 2017; Kasearu et al., 2017; Reeves et al., 2017). Additionally, research often shows that women represent the majority of members in social movements for environmental and animal protection (Puleo, 2017; Dimitro-

1 This research was supported by an internal research development grant at Leeds Beckett University, funded by HEFCE. 
polous, 2018). Therefore, it is relevant to connect the economics of women's experiences (i.e. feminist economics) with questions of equality, deprivation, policy, and sustainability. Because of the importance of the intersections of gender, policy, and sustainability, ecofeminism could certainly make a strong contribution to interrogating sustainable living and economies. However, ecofeminism has largely been separated from feminist economics, in part because its identity became tainted as a popular source of criticism by anti-feminist activists, and because concepts such as feminist environmentalism were favoured instead (Gaard, 2011). An unfortunate and unintended consequence of this separation seems to have disconnected questions of ecological sustainability and food security, which are rarely considered alongside research on wage gaps, women's and men's employment conditions, differences in the labour market, gender segregation in employment, roles in the household, the role of gender in poverty, and the increasing feminisation of poverty globally (Perkins et al., 2005).

To help re-establish the conceptual and data-driven connections between women, economics, and sustainability, this paper examines the direct interconnections between gender, class, food security, sustainability and food waste, and value-driven choices among women and men. By doing so, we link feminist economics and ecofeminism in the context of grocery shopping in the United Kingdom. This provides us with the opportunity to not only investigate feminist economics relative to women's position within a particular socioeconomic system, but also to position women's decision-making on a day-to-day basis within a larger value system connecting women's shopping habits with the ecofeminist argument that sustainability is a woman's issue.

As ecofeminism is neither second nor third-wave feminism (Gaard, 2010), so our paper is neither exclusively feminist economics or an ecofeminism piece. Instead, we aim to combine both distinctive perspectives and assess women's position in the sustainability debate using both concepts within the context of food shopping. In other words, our central assumptions are both that the earth is "being violated and degraded resulting in damage that is often irreparable, yet only a small proportion of humans have engaged their consciousness with this crisis" (Spretnak, 1990:2), and that sustainable living is necessary if we are to avoid an environmental catastrophe (Puleo, 2017). From these assumptions, our aim is to gain a better understanding of the extent to which women in a modern and relatively privileged society recognise sustainability-related issues when making routine decisions - like shopping for food. In doing so, we will have a better grasp on understanding the recognised importance of sustainability and the factors that both enable and limit sustainable decision-making on a routine basis. It is important to note that we follow an anti-essentialist view of ecofeminism in that we do not assume that women are more connected to nature than men; instead, we recognise that women's economics and lived realities place women's issues and sustainability as inextricably intertwined, and as such Puleo's (2017) perspective provides a meaningful grounding for this research. Puleo (2017) correctly argues that "the terms 'women' and 'ecology' are not synonyms. Being ecofeminist does not imply that women are innately more linked to nature and life than men. There are men who devote themselves to defending the 
environment and / or animals and women who are indifferent or hostile to these new forms of awareness" (Puleo, 2017:27). What is relevant for an ecofeminist position is the view that women are dominated in the same way nature is dominated, and thus protection of the environment becomes a true woman's issue.

In the following sections, we will introduce the context and rationale for this study, explore sustainability and ecofeminism, and show how women in the economy fit within this framework.

\subsection{Grocery shopping and sustainability debates in the $U K$}

Grocery shopping in the UK provides for a useful discussion of the intersection between gender, economics, and sustainability for several reasons. First, the UK has persistent class inequality, and class differences go so far that there can be a stigma attached to shopping at places that offer affordable prices. Shopping in different grocery stores is often viewed as an indicator of socioeconomic success and perceived deprivation. For example, shopping at stores such as Lidl has been seen by some as "social suicide" (Lowery, 2014; Topić and Tench, 2016) because stores like Lidl have generally been considered a discount shopping place for a demographic with less disposable income (Topić and Tench, 2016). Besides, there is a growing debate on sustainability such as the campaign on plastics, food waste, deforestation, which all have prominence in the British public sphere. Yet what is lacking in this context is a direct connection between people's attitudes about food waste with their attitudes regarding grocery shopping, different stores, yellow-sticker (i.e. discounted foods labelled with a yellow sticker in the supermarket) shopping, and their espoused values regarding environmental protection and ability to make sustainable consumption choices on a daily basis.

It is people's perceived empowerment to make sustainable choices that make it essential to examine women's place in the economy, and this makes feminist economics an integral part of the discussion. When it comes to women and the economy, much of the recent research has focused on employment and pay gap issues with discussions about the relative position of women in the economy. In the UK, for instance, Razzu and Singleton (2018) found that the employment rate gap between women and men has narrowed significantly in recent years. However, the economics of employment have not sufficiently narrowed indicating that occupational segregation remains rife in the labour market where women often work in less prestigious industries and earn less money (Barcena-Martin and Moro-Egido, 2013; Himmelweit, 2002; McKay et al., 2013; Razzu and Singleton, 2018). Thus, focusing on employment and the pay gap is useful, but it does not provide a complete picture of women's economic issues.

Feminist economics argues that the ways in which we measure "household", people's needs, and resource allocation are largely out of date (Cantillon and Nolan, 2001; Iversen, 2003; Shaffer, 2002; Wheelock et al., 2003). Some scholars argue that using gender to understand economic inequality provides a deeper understanding of those who are advantaged and disadvantaged within society (Warren, 2006; Corsi et al., 2016; Albelda, 2011; Bardasi and Gornick, 2008; Fukuda-Parr, 1999). However, the focus on gen- 
der alone is insufficient because it does not take into consideration other critical factors such as class (Hooks, 2000). As such, feminist economics affords us the opportunity to examine the intersections between gender and class.

In this paper, we are focusing on the dichotomy between women and men in an attempt to understand whether sustainability can be seen as a woman's issue. The intersectional examination of women in the economy in regards to both gender and class is particularly necessary for the UK because, as Pearson and Elson (2015) point out, the financial crisis, its aftermath, and the Conservative Party's austerity policies have disproportionately affected the most vulnerable women in British society, namely lone mothers, single women pensioners, and single women without children.

Feminist economics makes a strong case for the intersectional interrogation of gender and class, yet what also seems to be lacking in many of these discussions about the state of women in British society is the co-narrative of exploitation that goes beyond gendered identities into broader contexts.

\section{ECOFEMINISM, WOMEN, SUSTAINABILITY AND GROCERY SHOPPING}

Certainly, the issue of sustainability is not new in feminist and women's studies. Historically, ecology and the protection of the environment has been a part of the feminist movement since 1974, when Françoise d'Eaubonne coined the term "ecofeminism", even though environmental concerns have been a part of feminist ideologies much earlier, like those espoused by Rachel Carson (1962). Ecofeminism argues that the attitudes that lead to environmental degradation and women's oppression are grounded in the social construction of patriarchy where both women and nature are dominated as property (Adams, 2007; Holy, 2007; Geiger Zeman and Holy, 2014; Besthorn and Pearson McMillen, 2002; Warren, 2000; Emel, 1995; Salleh, 1992; Topić, 2020). ${ }^{2}$ They argue that the relationships of dominance and control of women and nature can be traced to the rise of patriarchal religion and religious culture dating back six to seven thousand years ago (John, 1988). Some of the environmental and ecological issues we face today come directly as a result of social structures that reinforce cultures of war, destruction, and dominance (Puleo, 2017).

\footnotetext{
2 Ecofeminism is more complex than what is outlined here, as there are some feminists who object to the above distinction calling it essentialist and sexist. For a full discussion, see: Plumwood, 1986 and MacGregor, 2004. In addition, some critiques also state that ecofeminism does not sufficiently address intersectionality and thus effectively undermines the ecological struggles of women of colour (for further discussion, see Gaard, 2010). However, ecofeminists also criticise environmentalists. For example, some ecofeminists feel that the turn towards environmentalism brings about a justification of human dominance over nature. In other words, by turning nature into environment represents a sign of human resistance to adjust to nature, and a move to gain power over nature. In this way, humans started to adjust nature to their own needs and exploit it, and this has destroyed the unity of nature and the natural order of things. In this situation, human becomes a man, nature becomes a woman, and humans then exercise power over nature while nature is controlled (Kirn, 1998; Cifrić, 1990; Buzov, 2007).
} 
As such, ecofeminism sees life on Earth as an interconnected network of individuals rather than a society where hierarchy is a natural order. In the ecofeminist view, human hierarchy is imposed on nature and then used to justify social dominance, and thus ecofeminism is essentially an anti-hierarchical feminist movement (King, 1989).

There is evidence, however, that hierarchy exists due to patriarchal structures that control the power, especially in capitalist Western societies, and this has resulted particularly in class inequalities and poverty. Ecofeminism, while inextricably linked to socialist feminism that also speaks of classes and inequality as most relevant for experiences of women in patriarchal societies, similarly speaks of the differences between women and men and discusses the notion of "otherness", where women and nature are seen as "others" and thus dominated and exploited. Many ecofeminists reject class as the only reason for subordination but argue that the notion of culture being above nature is what brings about the degradation of women seen as inextricably intertwined with nature (Galić and Geiger, 2007; Galić and Geiger, 2006).

Besides, ecofeminists argue that women are traditionally seen as chaotic, detached from reason, wild and emotional and thus animalistic. This same ideology is also applied to minority groups, for example, the Black race (Plumwood, 1994), and this ideology, in general, creates a sense of superiority by mankind often understood as white and male. In the same way, we can add that the class issue fits into this discourse because lower social classes are also sometimes seen in an unfavourable way, which in the UK, in particular, is manifested in low social mobility (Social Mobility Commission, 2019). We are, therefore, extending the usual ecofeminist method of analysing women by adding class as an issue which also bears relevance to women and their position in society.

Since 1974 there have certainly been important changes in our understanding of ecofeminism, our relationship with patriarchy, and our relationship with the environment that have resulted in substantial policy shifts supporting sustainability and gender equality (Buckingham, 2004). As already mentioned, while not all women care for the environment and ecological issues, and not all men seek to destroy it (Puleo, 2017; Spretnak, 1990), it is also important to recognise that women make up the majority of the members of movements that protect the environment and animals (Puleo, 2017:27). For example, Osprey Orielle Lake, founder of the Women's Earth and Climate Action Network, argues that many women often "lead on environmental and social legislation when elected to public office (...) countries with higher female parliamentary representation are more likely to ratify international environmental treaties" (Dimitropolous, 2018:80), and historically it has been feminists who joined protests for protection of the environment (Buzov, 2007). As such, it would be fair to predict that there would be differences between women and men with regard to general issues of sustainability. In more recent literature, some authors have proposed that ecofeminism should focus on "sustainability, human rights, with special attention to women's rights as they are the most ignored across cultures, and the treatment of animals" (Puleo, 2017:32). This advocacy for ecofeminist priorities, however, is not in conflict with the economy. In fact, ecofeminism has a history of economically sensitive advocacy, for example, d'Eaubonne 
(1990) provides a critical example of how sustainable living can be economically friendly by focusing on services rather than excessive production. Therefore, modern ecofeminism represents a rejection of exploitation across competition-based social systems - especially those that support excessive consumption and over-production (Besthorn and Pearson McMillen, 2002), which is where the link with socialist feminism also comes into play. However, in order to evaluate the impact that ecofeminism and women have on sustainability, it would be important to evaluate the degree to which women value sustainability, reduction of waste, and the rejection of overconsumption in their everyday lives. It is one thing to say that women advocate for international environmental treaties, the protection of animals, and gender equality; it is another to more directly measure the way that women live these ethics in their routine decisions and daily life.

One of the universal aspects of daily life is food consumption - from growing or buying food, to its consumption, and even waste. Parfitt et al. (2010) point out that in a global context food security is a genuine threat to the world's population, and that this is inexorably linked with issues of sustainable production. Yet the authors also found that one of the critical threats to the global food supply chain is post-consumer food waste in affluent economies, whereby affecting behavioural change in those economies is necessary in order to feed a growing global population sustainably (Parfitt et al., 2010). Using semi-structured interviews to explore the motivations and barriers in minimising household food waste, Graham-Rowe et al. (2014) found that in the UK values such as concerns over sustainability and ethical behaviour were underlying motivations for efforts to minimise household food waste. Graham-Rowe et al. (2015) followed up their interview-based research with a questionnaire-based analysis applying the extended theory of planned behaviour to food waste and found that factors like behavioural intention, attitude, subjective norm, perceived behavioural control, self-identity, and anticipated regret emerged as significant predictors of household food waste behaviour. The model also predicted food waste reduction when following up later with the participants. The data, therefore, very clearly demonstrate that values drive the post-consumer food waste likelihood in the UK. In short, they suggest that once the food is brought into the household, British consumers are conscious about using the food they have bought.

However, this does not explore the full "squander sequence" which includes consumer behaviours at the preacquisition, acquisition, consumption, and disposition stages (Block et al., 2016), only at the latter two stages. Block et al. (2016) argue that to fully understand sustainability in the food waste process, there needs to be a better understanding of the psychological underpinnings of consumer-level food waste. Research by Kelsey et al. (2018) demonstrates that the concept of yellow-sticker shopping can help researchers to better understand the preacquisition and acquisition stages of the squander sequence more effectively by focusing on the construction of social practices around yellow-sticker shopping. Yellow-sticker shopping involves consumers looking for food that is either damaged or nearing its sell-by date. In order to reduce overall food waste, consumers would need to not only reduce food waste in the post-consumer phase but also in the preacquisition and acquisition stages. 
One direct way to investigate these first two stages would be to examine factors influencing the grocery shopping intentions and behaviours of consumers to identify the degree to which values drive sustainable purchase and consumption. However, there is very little research connecting values to the entire squander sequence in the food waste process. Likewise, there is a fundamental lack of research exploring the gender influence on sustainability in food consumption and food waste.

\section{STUDY CONCEPTUALISATION}

The central objective of this study is to gain a better understanding of the tensions of patriarchy's reification across women's lives and its impact on the environment by analysing how women's concerns over consumption and disposition (ecofeminism) are related to the values and identities influencing their preacquisition behavioural intentions (feminist economics). Although previous authors (i.e. Block et al., 2016) discuss the squander sequence in a linear manner connected with the agricultural process, we are interested in the interconnections, identities, and attitudes that shape and inform the consumer component of this sequence. Ecofeminism and feminist economics perspectives would suggest that the squander sequence is not really a linear process; instead, it would be a self-reinforcing cycle of domination and subjugation (see Figure 1), which is consistent with other theories of behavioural change, such as the theory of planned behaviour that consider the factors that shape behavioural intention like prior experiences (e.g. Graham-Rowe et al., 2015). As such, we propose that without an improved understanding of the squander cycle, social norms surrounding food waste and food economy for women cannot be adequately addressed.
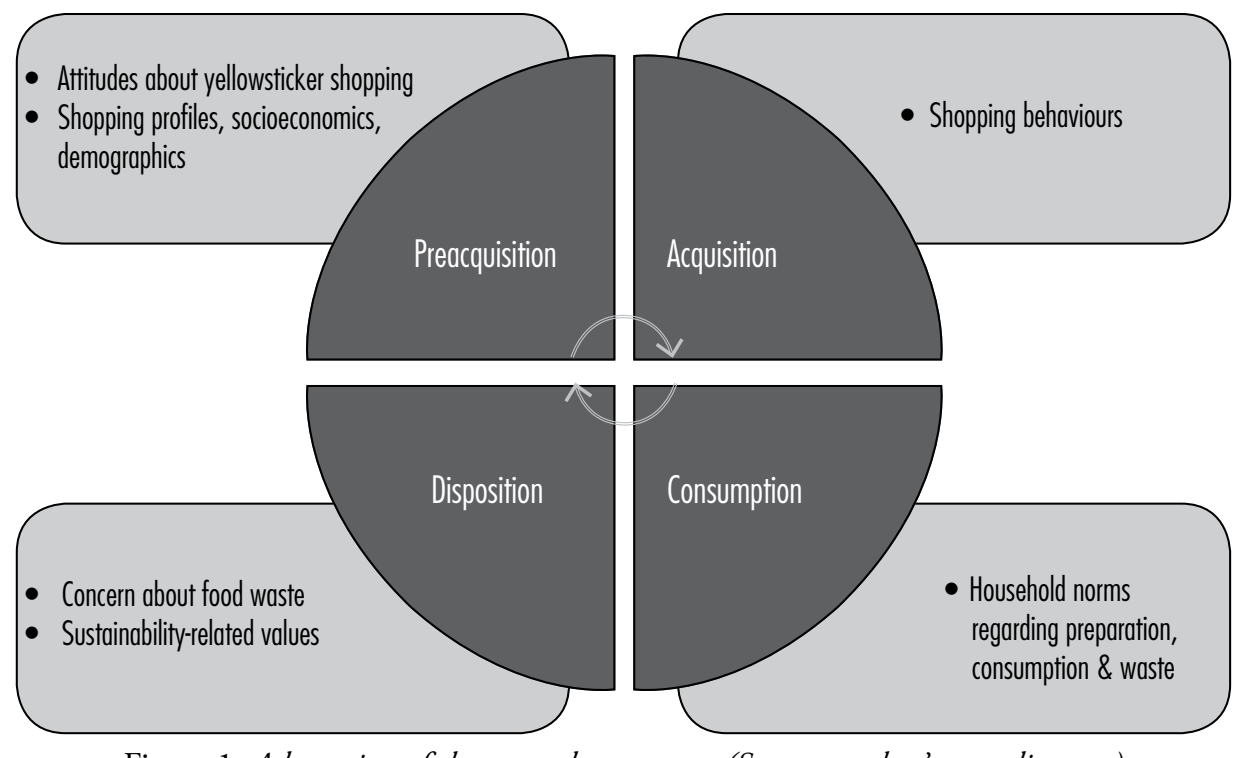

Figure 1. Adaptation of the squander sequence (Source: author's own diagram) 
In order to fully grasp the squander cycle from feminist economics and ecofeminist perspective and directly evaluate the influence these traditions have had in a modern British context, we posit the following research questions:

Research Question 1 (RQ1): Are there differences in food economy in the UK between women and men?

Research Question 2 (RQ2): What factors contribute to women's evaluations of yellow-sticker food shopping?

Research Question 3 (RQ3): What factors contribute to women's identification with reduced-price shopping profiles?

Research Question 4 (RQ4): What factors influence women's perceptions of food waste?

\section{METHODOLOGY}

\subsection{Method}

This study uses quantitative questionnaire-based data to answer these research questions so as to better understand the interrelationships between ecofeminism and feminist economics in the context of food waste grocery shopping in the UK. Certainly, there are many critical scholars, like Hozić and True (2017), who argue against the appropriateness or validity of quantitative methods when exploring issues related to power and social justice. However, we would argue that in order to appropriately investigate, expose, and develop meaningful change against these structures (i.e. central objectives in a critical ontology, Corman, 2000), it can be very useful to borrow post-positivist methodologies, which are also grounded in realism, to test our assumptions and generate knowledge (Corman, 2000) that should ground advocacy. In Miller's (2000) analysis on the interconnections between ontology and methods, she argues:

“...dimensions [of ontology]...that look neat and clean....are not nearly so tidy....Instead, for practicing scholars those boundaries are blurry, they are... 'jumped' as the needs of specific research projects evolve. But perhaps the most important insight here is that these typologies can serve as a straight-jacket, constraining researchers... rather than to explore research questions that are important" (Corman, 2000:48).

Essentially, we argue that research questions that investigate identities, values, and their influence over our routine decisions and sustainability are fundamentally important questions if societies are to change, adapt, and ensure a future. As such, this project's aims can best be achieved by blending critical and post-positivist perspectives in a post-positivist methodology in order to try to generate actionable reflections on women, sustainability, and the squander cycle regarding food consumption.

\subsection{Procedures and Sample}

The data were collected on a UK-wide population sample using a purchased Smart Survey 20-minute online questionnaire. A data set of 792 complete responses was included in the data analysis. We have an expected sample from across the UK segmented for 
gender (where $51 \%$ of participants identified as women and $49 \%$ of participants identified as men) and region (see Table 1). There was an expected distribution ${ }^{3}$ of household incomes with a median income of approximately $£ 30,000$ (i.e. $41.6 \%$ of all participants had an income between $£ 20,000$ and 39,000 with the median in the $£ 30,000$ band). Additionally, there is an expected household composition with a mean household size of 2.7 people. Finally, there was an expected distribution of employment with a $74 \%$ employment rate in the sample compared to an overall $75.6 \%$ Labour Force survey finding on UK-wide employment in a survey conducted between October to December 2017 and January to March 2018 (Wilson, 2018). In all, the data suggest that our sample is representative of the larger UK population within a reasonable error rate.

Table 1. Distribution of participants from the UK

\begin{tabular}{|l|c|c|c|}
\hline & N & $\%$ & \% UK Population \\
\hline East of England & 64 & 8.1 & 9.3 \\
\hline London & 123 & 15.5 & 13.3 \\
\hline Midlands & 123 & 15.5 & 16 \\
\hline NE, Yorkshire, \& the Humber & 97 & 12.2 & 12.2 \\
\hline Northwest & 86 & 10.9 & 10.9 \\
\hline Northern Ireland & 23 & 2.9 & 2.8 \\
\hline Scotland & 67 & 8.5 & 8.2 \\
\hline South East & 104 & 13.1 & 13.7 \\
\hline South West & 67 & 8.5 & 8.4 \\
\hline Wales & 38 & 4.8 & 4.7 \\
\hline
\end{tabular}

\subsection{Data Operationalisation and Analysis}

Along with the demographic and socioeconomic data, the questionnaire featured questions evaluating the perceived quality of yellow-sticker food (Aschemann-Witzel et al., 2018a; de Hooge et al. 2017), shopper profile (Aschemann-Witzel et al., 2018b); self-reported food waste behaviours (Aschemann-Witzel et al., 2018b; Achemann-Witzel et al., 2017), and value orientation (Alcock, 2012; De Groot and Steg, 2008) together with some original measures adapted to the research context and questions. An exploratory factor analysis was conducted, followed up by Cronbach's alpha to verify the reliability of the measures resulting in the operationalisation of the study variables as listed in Table 2. All scales were five-point Likert type scales with 5 representing the highest value (i.e. 1 = "strongly disagree" to 5 = "strongly agree").

3 According to the Office for National Statistics (ONS), the UK median income was $£ 27,300$ for 2017 and the mean household size is 2.4 people.

4 Based on data from the Office of National Statistics (2018) and Statista (2020). 


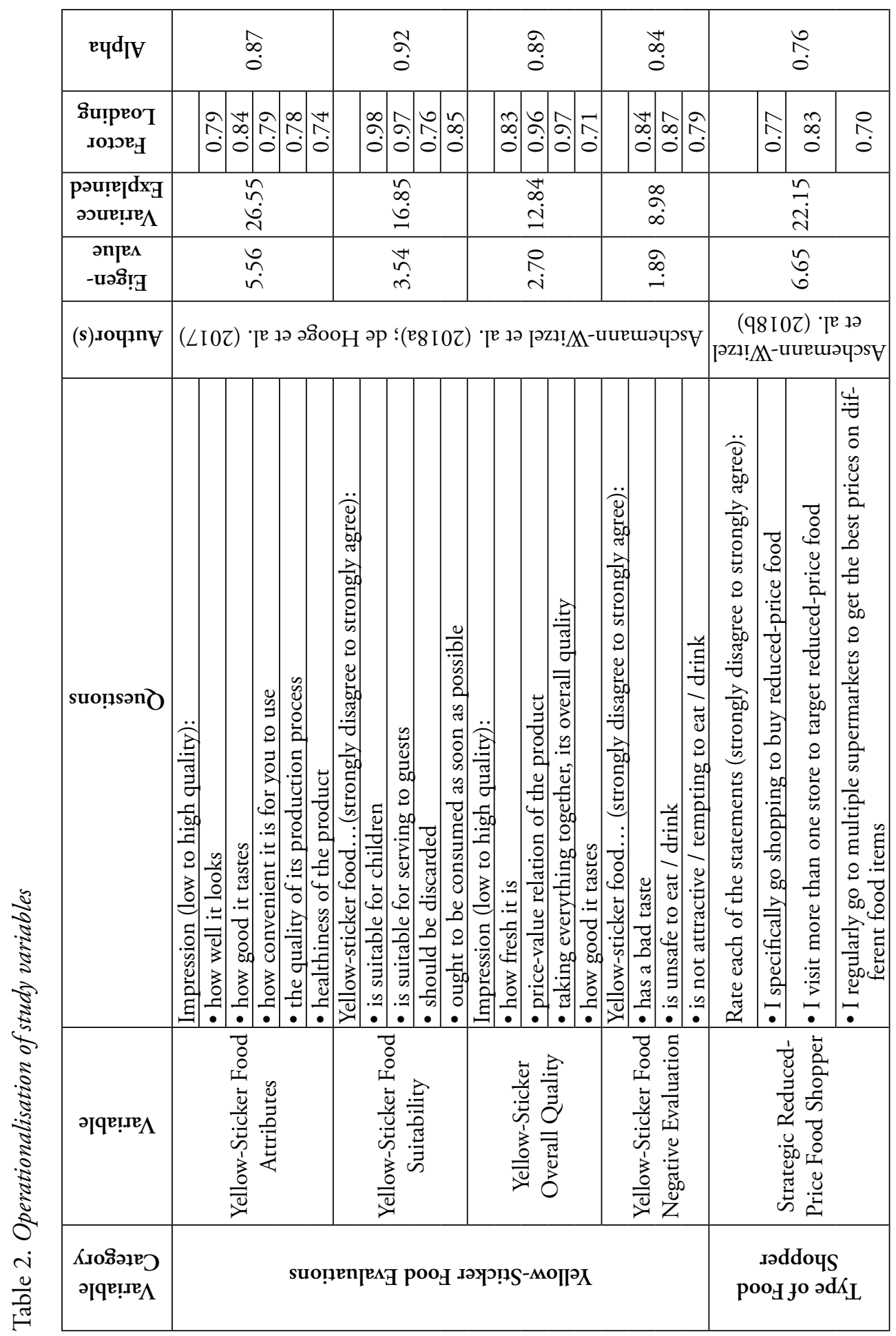


Soc. ekol. Zagreb, Vol. 30 (2021.), No. 2

Martina Topić et al.: Women and the Squander Cycle in Food Waste (UK): An Ecofeminist and Economics Analysis

\begin{tabular}{|c|c|c|c|c|c|c|c|c|c|c|c|c|c|c|c|c|c|}
\hline & & $\begin{array}{l}\stackrel{0}{\infty} \\
\stackrel{0}{0}\end{array}$ & & & & $\overparen{\sigma}$ & & & & & $\begin{array}{l}\stackrel{8}{\infty} \\
\stackrel{0}{0}\end{array}$ & & & & & & $\underset{\zeta}{\Xi}$ \\
\hline & $\vec{a}$ & $\stackrel{+}{0}$ & $\begin{array}{l}\text { ல0. } \\
0 \\
0\end{array}$ & $\stackrel{n}{\mathfrak{o}}$ & & $\begin{array}{l}\hat{\sigma} \\
\dot{0}\end{array}$ & $\underset{0}{\text { రై }}$ & $\mid \begin{array}{l}\infty \\
0 \\
0\end{array}$ & & 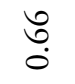 & $\stackrel{+}{0}$ & $\begin{array}{l}\infty \\
\infty \\
0 \\
0\end{array}$ & & 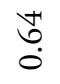 & ڤิ & $\mid \begin{array}{c}0 \\
\infty \\
\dot{0}\end{array}$ & $\begin{array}{l}\infty \\
\infty \\
0\end{array}$ \\
\hline & & $\begin{array}{l}\stackrel{+}{0} \\
\stackrel{-}{0}\end{array}$ & & & & $\underset{\infty}{\infty}$ & & & & & ఫે & & & & & & $\begin{array}{l}\text { ô } \\
\text { in }\end{array}$ \\
\hline & & 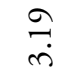 & & & & $\underset{\cup}{\infty}$ & & & & & $\begin{array}{l}\infty \\
\stackrel{\circ}{\sim} \\
\text { i }\end{array}$ & & & & & & ํ. \\
\hline & & & & & & & BI0Z) & • & $\mathrm{z} 1$ & -uU & Шә૫ & $S \forall$ & & & & & \\
\hline 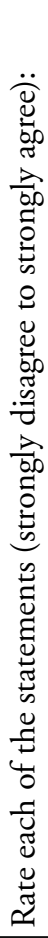 & 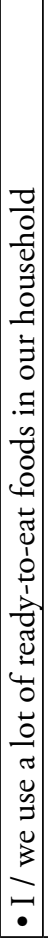 & 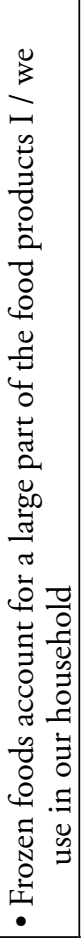 & 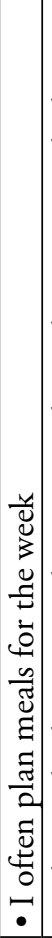 & 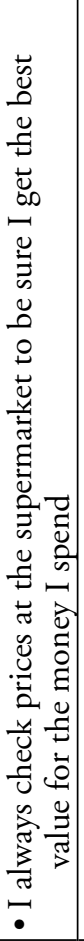 & 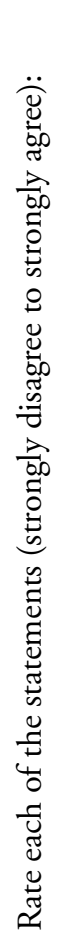 & 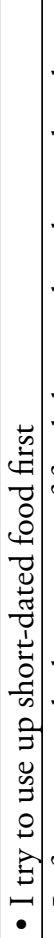 & 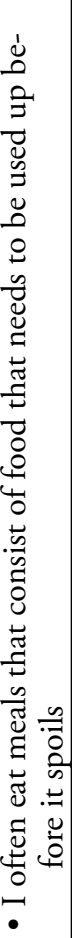 & 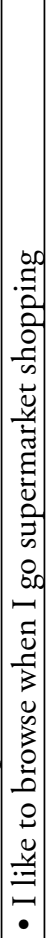 & 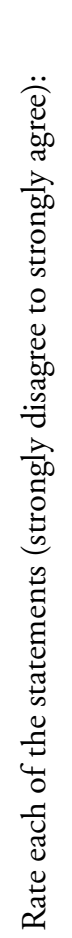 & 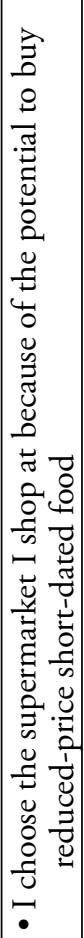 & 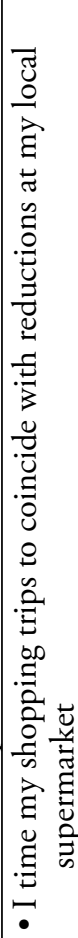 & 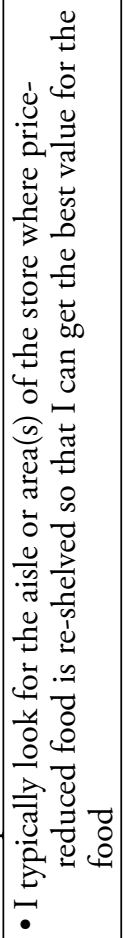 & 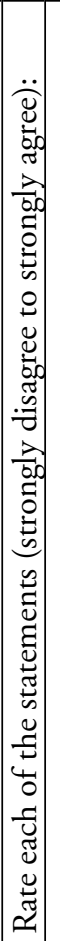 & 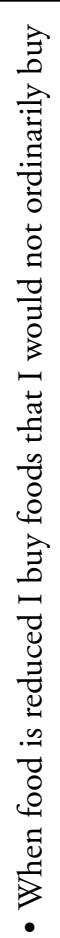 & 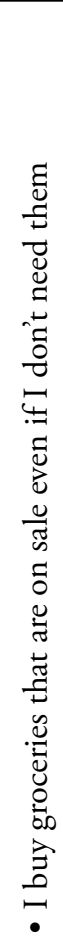 & 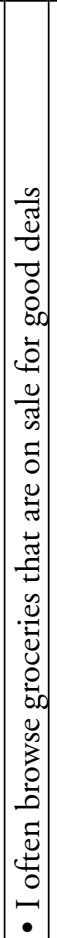 & 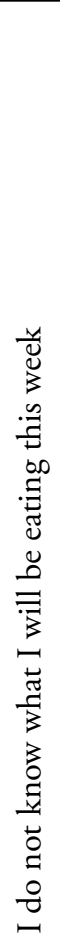 \\
\hline & & 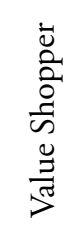 & & & & 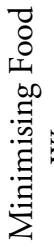 & & & & & 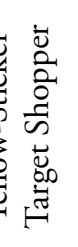 & & & & $\begin{array}{l}\dot{\bar{\Xi}} \\
\frac{a}{0} \\
\frac{0}{\infty}\end{array}$ & & 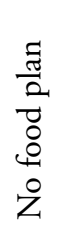 \\
\hline & & & & & & & & & S po & jo & $K_{\mathrm{L}}$ & & & & & & \\
\hline
\end{tabular}


Soc. ekol. Zagreb, Vol. 30 (2021.), No. 2

Martina Topic et al.: Women and the Squander Cycle in Food Waste (UK): An Ecofeminist and Economics Analysis

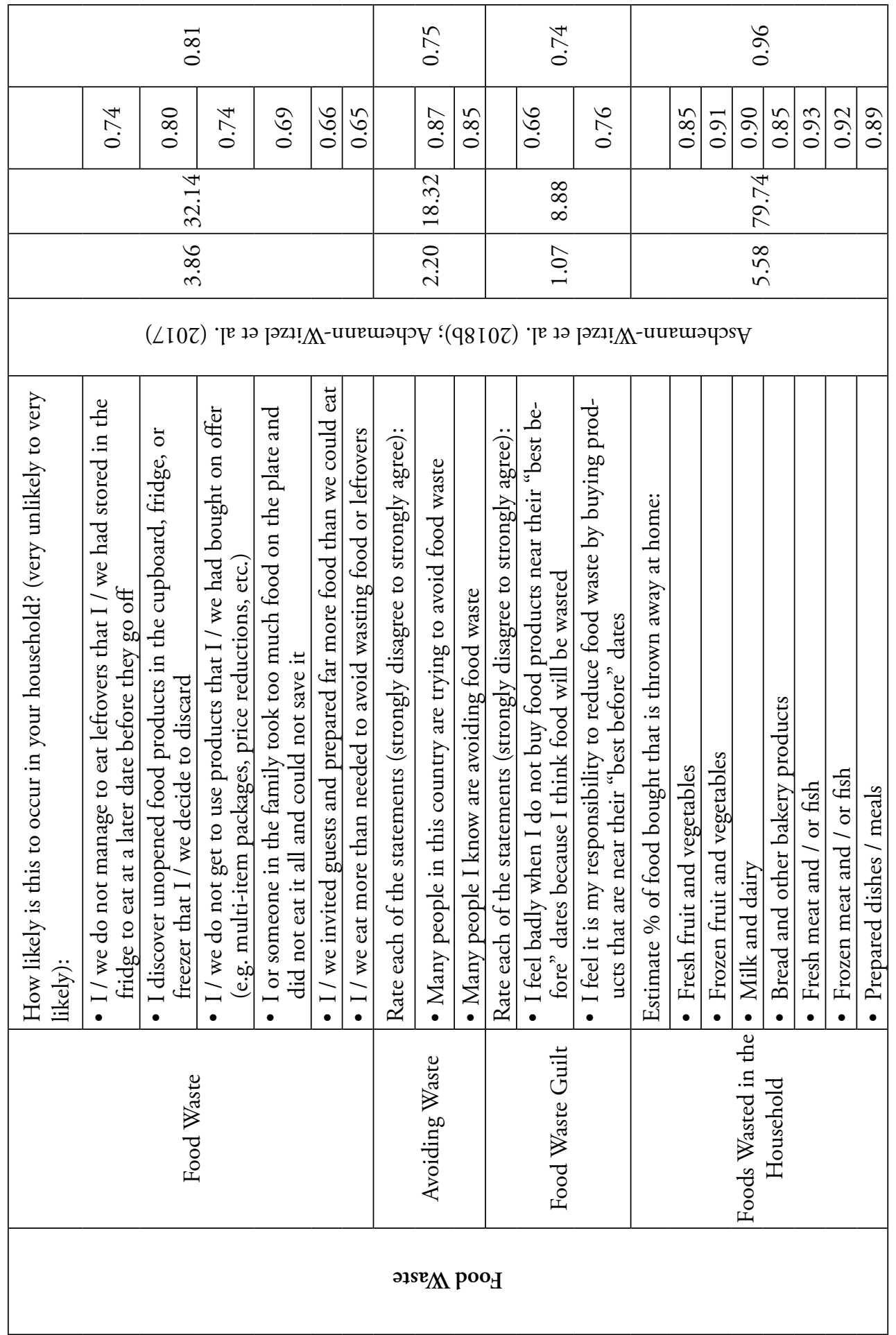




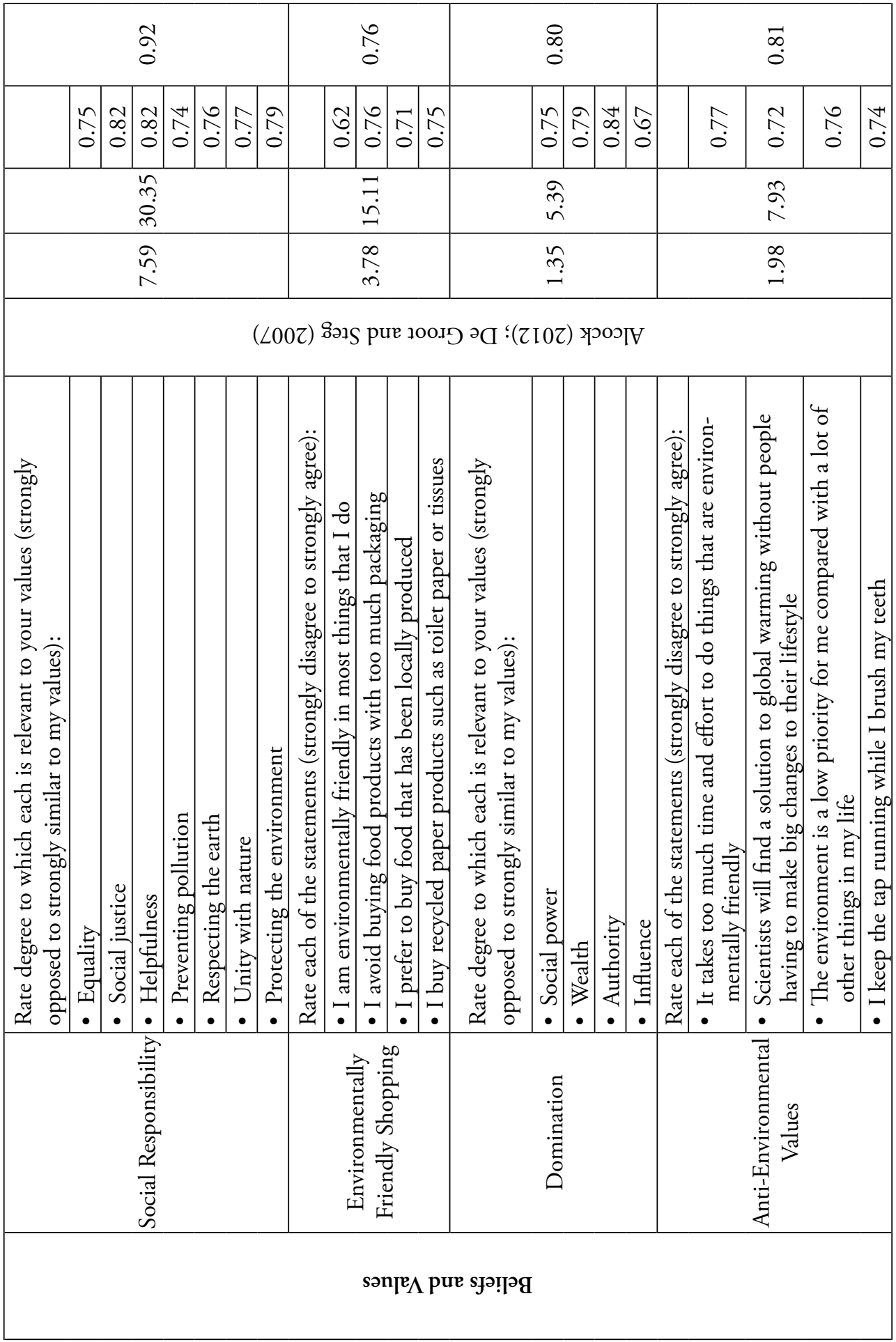


In order to first justify the assumption that women and men would have significantly different views on food consumption and answer RQ1, we ran ANOVA using gender as the independent variable and all outcome variables as dependent variables. For the remaining research questions, correlations were first run between each of the dependent variables and the independent variables to establish significant relationships and then hierarchical multiple regression tests were performed entering demographic IVs, then socioeconomic IVs, shopping profiles, and then values, thus minimising the multi-collinearity in the regression equations. Additionally, to determine variances in women's evaluation of yellow-sticker shopping and shopping profiles for RQ2 and RQ3, paired $\mathrm{t}$-tests were run to further explore differences.

\section{RESULTS}

The data provide some important insights regarding differences between women's and men's perspectives on the squander sequence and give a deeper understanding of the relationship between the factors that drive women's approach to grocery shopping revealing the importance of both economic and value-based decision-making.

\subsection{RQ1: Differences Between Women's and Men's Attitudes}

Overall, the data (see Table 3) demonstrate that women and men see grocery economy differently, which goes in line with the ecofeminist argument of women having different perspectives. Women tend to be focused on minimising potential money wasted by taking a more conservative approach to food spending decisions. Men tend to look for the best deals while maintaining the perceived highest quality food. Where differences in spending occur, men tend to spend more money on groceries and have a significantly higher negative evaluation of yellow-sticker food than women. These results warrant analysing women's evaluations of food economy separately from that of men. As such, our first assumption that the food economy is a distinctive issue based on gender is verified by these data in the UK.

Table 3. Significant one-way ANOVA results for gender and food economy

\begin{tabular}{|c|c|c|c|c|c|c|c|c|}
\hline $\begin{array}{c}\text { DV } \\
\text { Category }\end{array}$ & DV & $\mathrm{M} / \mathrm{F}$ & $\mathrm{N}$ & M & SD & df & $\mathrm{F}$ & $\mathrm{p}$ \\
\hline \multirow{4}{*}{ 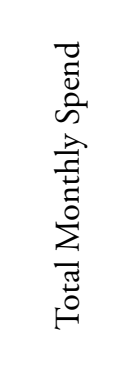 } & M\&S Simply Food & $\begin{array}{c}M \\
F\end{array}$ & $\begin{array}{l}387 \\
401\end{array}$ & $\begin{array}{l}285.80 \\
270.53\end{array}$ & $\begin{array}{l}194.54 \\
179.50\end{array}$ & $1 ; 787$ & 12.25 & 0.00 \\
\hline & Sainsbury's & $\begin{array}{c}\mathrm{M} \\
\mathrm{F}\end{array}$ & $\begin{array}{l}387 \\
401\end{array}$ & $\begin{array}{l}40.52 \\
29.50\end{array}$ & $\begin{array}{l}93.51 \\
54.57\end{array}$ & $1 ; 786$ & 4.12 & 0.04 \\
\hline & Tesco & $\begin{array}{c}\mathrm{M} \\
\mathrm{F}\end{array}$ & $\begin{array}{l}387 \\
401\end{array}$ & $\begin{array}{l}80.69 \\
64.66\end{array}$ & $\begin{array}{c}121.55 \\
93.71\end{array}$ & $1 ; 786$ & 4.32 & 0.04 \\
\hline & ASDA & $\begin{array}{c}\mathrm{M} \\
\mathrm{F}\end{array}$ & $\begin{array}{l}386 \\
401\end{array}$ & $\begin{array}{l}32.15 \\
46.05\end{array}$ & $\begin{array}{l}72.15 \\
87.20\end{array}$ & $1 ; 785$ & 5.92 & 0.02 \\
\hline
\end{tabular}


Soc. ekol. Zagreb, Vol. 30 (2021.), No. 2

Martina Topić et al.: Women and the Squander Cycle in Food Waste (UK): An Ecofeminist and Economics Analysis

\begin{tabular}{|c|c|c|c|c|c|c|c|c|}
\hline \multirow{2}{*}{ 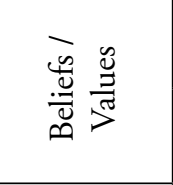 } & Social Responsibility & $\begin{array}{c}M \\
F\end{array}$ & $\begin{array}{l}388 \\
402\end{array}$ & $\begin{array}{l}3.81 \\
3.96\end{array}$ & $\begin{array}{l}0.80 \\
0.72\end{array}$ & $1 ; 788$ & 6.92 & 0.01 \\
\hline & $\begin{array}{l}\text { Anti- } \\
\text { Environmentalism }\end{array}$ & $\begin{array}{c}\mathrm{M} \\
\mathrm{F} \\
\end{array}$ & $\begin{array}{l}388 \\
402 \\
\end{array}$ & $\begin{array}{l}2.72 \\
2.50 \\
\end{array}$ & $\begin{array}{l}0.96 \\
0.93 \\
\end{array}$ & $1 ; 788$ & 10.20 & 0.00 \\
\hline 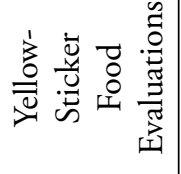 & Negative Evaluation & $\begin{array}{c}\mathrm{M} \\
\mathrm{F}\end{array}$ & $\begin{array}{l}388 \\
402\end{array}$ & $\begin{array}{l}2.65 \\
2.49\end{array}$ & $\begin{array}{l}0.98 \\
0.96\end{array}$ & $1 ; 788$ & 4.99 & 0.03 \\
\hline 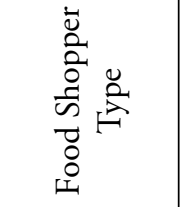 & $\begin{array}{l}\text { Shop to Minimise } \\
\text { Food Waste }\end{array}$ & $\begin{array}{c}\mathrm{M} \\
\mathrm{F}\end{array}$ & $\begin{array}{l}388 \\
402\end{array}$ & $\begin{array}{l}3.71 \\
3.86\end{array}$ & $\begin{array}{l}0.70 \\
0.67\end{array}$ & $1 ; 788$ & 9.87 & 0.00 \\
\hline 葡 & $\begin{array}{l}\text { Avoiding Food } \\
\text { Waste }\end{array}$ & $\begin{array}{l}\mathrm{M} \\
\mathrm{F} \\
\end{array}$ & $\begin{array}{l}388 \\
402 \\
\end{array}$ & $\begin{array}{l}3.25 \\
3.41 \\
\end{array}$ & $\begin{array}{l}0.87 \\
0.87 \\
\end{array}$ & $1 ; 788$ & 6.57 & 0.01 \\
\hline : & $\begin{array}{l}\text { Percentage Estimate } \\
\text { of Food Wasted in } \\
\text { Household }\end{array}$ & $\begin{array}{c}\mathrm{M} \\
\mathrm{F}\end{array}$ & $\begin{array}{l}388 \\
402\end{array}$ & $\begin{array}{l}23.32 \\
20.08\end{array}$ & $\begin{array}{l}25.04 \\
21.80\end{array}$ & $1 ; 788$ & 3.77 & 0.05 \\
\hline \multirow{8}{*}{ 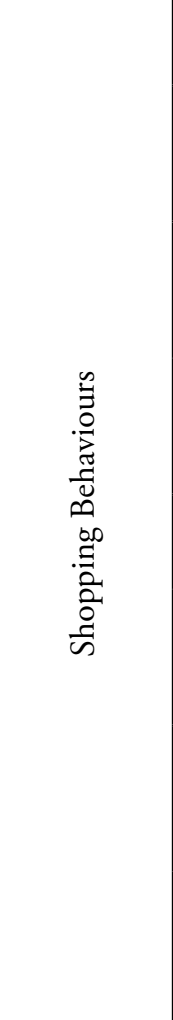 } & $\begin{array}{l}\text { Shopper, Cooking } \\
\text { Same Person }\end{array}$ & $\begin{array}{c}\mathrm{M} \\
\mathrm{F}\end{array}$ & $\begin{array}{l}387 \\
402\end{array}$ & $\begin{array}{l}3.70 \\
4.00\end{array}$ & $\begin{array}{l}1.22 \\
1.18\end{array}$ & $1 ; 787$ & 12.35 & 0.00 \\
\hline & $\begin{array}{l}\text { Apples, optimal } \\
\text { quality, short use-by } \\
\text { date, price-reduced }\end{array}$ & $\begin{array}{c}\mathrm{M} \\
\mathrm{F}\end{array}$ & $\begin{array}{l}388 \\
402\end{array}$ & $\begin{array}{l}0.23 \\
0.15\end{array}$ & $\begin{array}{l}0.42 \\
0.36\end{array}$ & $1 ; 788$ & 9.38 & 0.00 \\
\hline & $\begin{array}{l}\text { Bananas, sub- } \\
\text { optimal, price- } \\
\text { reduced }\end{array}$ & $\begin{array}{c}M \\
F\end{array}$ & $\begin{array}{l}388 \\
402\end{array}$ & $\begin{array}{l}0.39 \\
0.29\end{array}$ & $\begin{array}{l}0.49 \\
0.46\end{array}$ & $1 ; 788$ & 8.98 & 0.00 \\
\hline & $\begin{array}{l}\text { Chicken, sub- } \\
\text { optimal, price- } \\
\text { reduced }\end{array}$ & $\begin{array}{c}M \\
F\end{array}$ & $\begin{array}{l}388 \\
402\end{array}$ & $\begin{array}{l}0.51 \\
0.40\end{array}$ & $\begin{array}{l}0.50 \\
0.49\end{array}$ & $1 ; 788$ & 10.62 & 0.00 \\
\hline & $\begin{array}{l}\text { Salmon, optimal, } \\
\text { full-price }\end{array}$ & $\begin{array}{c}\mathrm{M} \\
\mathrm{F}\end{array}$ & $\begin{array}{l}388 \\
402 \\
\end{array}$ & $\begin{array}{l}0.14 \\
0.09\end{array}$ & $\begin{array}{l}0.35 \\
0.29\end{array}$ & $1 ; 788$ & 5.79 & 0.02 \\
\hline & $\begin{array}{l}\text { Beef mince, optimal, } \\
\text { short use-by date, } \\
\text { price reduced }\end{array}$ & $\begin{array}{c}\mathrm{M} \\
\mathrm{F}\end{array}$ & $\begin{array}{l}388 \\
402\end{array}$ & $\begin{array}{l}0.38 \\
0.31\end{array}$ & $\begin{array}{l}0.49 \\
0.46\end{array}$ & $1 ; 788$ & 4.68 & 0.03 \\
\hline & $\begin{array}{l}\text { Milk, optimal, short } \\
\text { use-by date, price } \\
\text { reduced }\end{array}$ & $\begin{array}{c}M \\
F\end{array}$ & $\begin{array}{l}388 \\
402\end{array}$ & $\begin{array}{l}0.31 \\
0.25\end{array}$ & $\begin{array}{l}0.47 \\
0.43\end{array}$ & $1 ; 788$ & 4.23 & 0.04 \\
\hline & $\begin{array}{l}\text { Beans, optimal, } \\
\text { damaged can, price- } \\
\text { reduced }\end{array}$ & $\begin{array}{c}\mathrm{M} \\
\mathrm{F}\end{array}$ & $\begin{array}{l}388 \\
402\end{array}$ & $\begin{array}{l}0.52 \\
0.41\end{array}$ & $\begin{array}{l}0.50 \\
0.49\end{array}$ & $1 ; 788$ & 11.13 & 0.00 \\
\hline
\end{tabular}




\subsection{RQ2: Factors Influencing Women's Evaluations of Yellow-Sticker Food Shopping}

Overall, the data suggest that values are the most important predictors of the ways in which women evaluate yellow-sticker food shopping. However, the data also reveal that socioeconomics have a significant influence in how women evaluate yellow-sticker food shopping.

Positive attributes of yellow-sticker food: Two variables were significantly correlated with positive attributes of yellow-sticker food: value of social responsibility $(r=0.14$, $\mathrm{p}<0.01)$, and positive affect for environmentally friendly shopping $(\mathrm{r}=0.23, \mathrm{p}<0.01)$ (see Table 2). The data suggest (see Table 4) that while core demographics and household characteristics do not meaningfully predict positive attributes that women make towards yellow-sticker food, values do. Specifically, the more that women identify with the values of social responsibility and environmentally-friendly shopping, the more likely they are to view yellow-sticker food as having positive attributes. This accounts for a small but meaningful five percent of the variance in women's attribute evaluations of yellow-sticker food.

Table 4. Regression model for yellow-sticker food evaluation: positive attributes

\begin{tabular}{|l|c|c|c|}
\hline \multicolumn{1}{|c|}{ Regressor } & Beta & Model 1 SE & t \\
\hline Intercept & 2.50 & 0.22 & 11.38 \\
\hline Social Responsibility & 0.06 & 0.05 & 1.19 \\
\hline $\begin{array}{l}\text { Positive Affect for Environmentally } \\
\text { Friendly Shopping }\end{array}$ & 0.21 & 0.05 & $4.07^{* * *}$ \\
\hline $\mathrm{F}$ & & $12.25^{* * *}$ & \\
\hline$\Delta \mathrm{F}$ & & & \\
\hline $\mathrm{R}^{2}$ & & 0.06 & \\
\hline $\mathrm{R}^{2}$ adj. & & 0.05 & \\
\hline $\mathrm{R}^{2}$ change & & 0.06 & \\
\hline $\mathrm{df}$ & & $2 ; 399$ & \\
\hline
\end{tabular}

Notes: ${ }^{*} \mathrm{p}<0.05,{ }^{* *} \mathrm{p}<0.01,{ }^{* * *} \mathrm{p}<0.001$

Suitability of yellow-sticker food: Four variables were significantly correlated with evaluations that yellow-sticker food is suitable for consumption in different settings: total monthly spend on food shopping $(r=0.11, p<0.05)$, value of social responsibility $(r=0.16, p<0.01)$, positive affect for environmentally friendly shopping $(r=0.25, \mathrm{p}<0.01)$, and value of domination $(r=0.15$, $\mathrm{p}<0.01$ ) (see Table 2). The data suggest (see Table 5) that while the total amount of money that women's households spend on grocery shopping each month is a significant predictor of their evaluation of the suitability of yellow-sticker food for consumption, it only accounts for approximately one percent of the variance in this evaluation. Women's values are a much more important predictor of this evaluation. Though significantly correlated, valuing social responsibility does not significantly predict suitability evaluations of yellow-sticker food. However, valuing environmentally friendly shopping and domination values are more meaningful predictors, accounting for an additional eight percent of the variance in women's suitability attitudes. 
Table 5. Regression model for yellow-sticker food evaluation: suitability

\begin{tabular}{|l|c|c|c|c|c|c|}
\hline \multicolumn{1}{|c|}{ Regressor } & Beta & $\begin{array}{c}\text { Model 1 } \\
\text { SE }\end{array}$ & $\mathbf{t}$ & Beta & $\begin{array}{c}\text { Model 2 } \\
\text { SE }\end{array}$ & t \\
\hline Intercept & & 0.04 & 77.29 & & 0.17 & 13.90 \\
\hline $\begin{array}{l}\text { Total Monthly Spend on Food } \\
\text { Shopping }\end{array}$ & 0.00 & 0.11 & $2.13^{*}$ & 0.10 & 0.00 & $2.07^{*}$ \\
\hline Social Responsibility & & & & 0.07 & 0.03 & 1.31 \\
\hline $\begin{array}{l}\text { Positive Affect for Environmentally } \\
\text { Friendly Shopping }\end{array}$ & & & & 0.22 & 0.03 & $4.30^{* * *}$ \\
\hline Domination & & & & 0.14 & 0.03 & $2.99^{* * *}$ \\
\hline $\mathrm{F}$ & & $4.53^{*}$ & & & $10.33^{* * *}$ & \\
\hline$\Delta \mathrm{F}$ & & $4.53^{*}$ & & & $12.13^{* * *}$ & \\
\hline $\mathrm{R}^{2}$ & & 0.01 & & & 0.10 & \\
\hline $\mathrm{R}_{\text {adj. }}^{2}$ & & 0.01 & & & 0.09 & \\
\hline $\mathrm{R}^{2}$ change & & 0.01 & & & 0.08 & \\
\hline $\mathrm{df}$ & & $1 ; 395$ & & & $4 ; 392$ & \\
\hline
\end{tabular}

Notes: ${ }^{*} \mathrm{p}<0.05,{ }^{* *} \mathrm{p}<0.01,{ }^{* * *} \mathrm{p}<0.001$

Overall quality impressions of yellow-sticker food: Three variables were significantly correlated with the overall quality impressions of yellow-sticker food: education $(r=0.12, p<0.05)$, value of social responsibility $(\mathrm{r}=0.14, \mathrm{p}<0.01)$, and positive affect for environmentally friendly shopping $(\mathrm{r}=0.24, \mathrm{p}<0.01)$ (see Table 2 ). The data suggest (see Table 6$)$ that women who are more educated are more likely to view yellow-sticker food as having a higher overall quality compared to those with less education. This had a relatively weak effect, only predicting about one percent of the variance in women's attitudes about quality. Additionally, while social responsibility is significantly correlated with women's evaluations of the overall quality of yellow-sticker food, it was not a significant predictor in the regression model. However, valuing environmentally-friendly shopping was a significant and more meaningful predictor of women's attitudes about the overall quality of yellow-sticker food, accounting for six percent of the variance.

Table 6. Regression model for yellow-sticker food: overall quality

\begin{tabular}{|l|c|c|c|c|c|c|}
\hline \multicolumn{1}{|c|}{ Regressor } & Beta & $\begin{array}{c}\text { Model 1 } \\
\text { SE }\end{array}$ & t & Beta & $\begin{array}{c}\text { Model 2 } \\
\text { SE }\end{array}$ & t \\
\hline Intercept & & 0.11 & 30.62 & & 0.25 & 8.77 \\
\hline Education & 0.12 & 0.03 & $2.39^{*}$ & 0.11 & 0.03 & $2.36^{*}$ \\
\hline Social Responsibility & & & & 0.06 & 0.05 & 1.22 \\
\hline $\begin{array}{l}\text { Positive Affect for Environmentally } \\
\text { Friendly Shopping }\end{array}$ & & & & 0.22 & 0.05 & $4.20^{* * *}$ \\
\hline $\mathrm{F}$ & & $5.73^{*}$ & & & $10.71^{* * *}$ & \\
\hline$\Delta \mathrm{F}$ & & $5.73^{*}$ & & & $13.02^{* * *}$ & \\
\hline $\mathrm{R}^{2}$ & & 0.01 & & & 0.08 & \\
\hline
\end{tabular}




\begin{tabular}{|l|c|c|c|c|c|c|}
\hline $\mathrm{R}_{\text {adj. }}^{2}$ & & 0.01 & & & 0.07 & \\
\hline $\mathrm{R}^{2}$ change & & 0.01 & & & 0.06 & \\
\hline $\mathrm{df}$ & & $1 ; 400$ & & & $3 ; 398$ & \\
\hline
\end{tabular}

Notes: ${ }^{*} \mathrm{p}<0.05,{ }^{* *} \mathrm{p}<0.01,{ }^{* * *} \mathrm{p}<0.001$

Negative evaluation of yellow-sticker food: Six variables were significantly correlated with the negative evaluation of yellow-sticker food: age $(r=-0.14, p<0.01)$, education $(r=-0.13, p<0.01)$, number of people living in a household $(\mathrm{r}=0.14, \mathrm{p}<0.01)$, value of social responsibility $(\mathrm{r}=-$ $0.22, \mathrm{p}<0.01)$, value of domination $(\mathrm{r}=0.21, \mathrm{p}<0.01)$, and anti-environmental attitudes $(\mathrm{r}=0.43$, $\mathrm{p}<0.01$ ) (see Table 2). The data (see Table 7) suggest that personal demographics, household demographics, and values all significantly predict negative evaluations of yellow-sticker food, with values being the most important predictor. Initially, young women and those with less education are significantly more likely to hold negative attitudes about yellow-sticker food, accounting for four percent of the variance. Additionally, while it has a small effect when women live in households with more people, they are more likely to have negative evaluations of yellow-sticker food. Though the values of social responsibility and domination were significantly correlated, they were not predictive of women's negative attitudes towards yellow-sticker food. However, there was a strong effect for anti-environmental values and negative feelings about yellow-sticker food. Together, this regression model predicts about one-fifth of the variance in women's negative attitudes towards yellow-sticker food.

Table 7. Regression model for yellow-sticker food: negative evaluation

\begin{tabular}{|l|c|c|c|c|c|c|c|c|c|}
\hline \multicolumn{1}{|c|}{ Regressor } & Beta & $\begin{array}{c}\text { Model } \\
\text { 1 SE }\end{array}$ & $\mathbf{t}$ & Beta & $\begin{array}{c}\text { Model } \\
\text { 2 SE }\end{array}$ & $\mathbf{t}$ & Beta & $\begin{array}{c}\text { Model 3 } \\
\text { SE }\end{array}$ & t \\
\hline Intercept & & 0.22 & 15.44 & & 0.27 & & & 0.44 & \\
\hline Age & -0.16 & 0.04 & $-3.14^{* *}$ & -0.12 & 0.04 & $-2.37^{*}$ & -0.06 & 0.04 & -1.28 \\
\hline Education & -0.15 & 0.04 & $-3.02^{* *}$ & -0.14 & 0.04 & $-2.94^{* *}$ & -0.13 & 0.04 & $-2.96^{* *}$ \\
\hline $\begin{array}{l}\text { N Living in } \\
\text { Household }\end{array}$ & & & & 0.10 & 0.04 & $1.93^{*}$ & 0.04 & 0.04 & 0.88 \\
\hline $\begin{array}{l}\text { Social } \\
\text { Responsibility }\end{array}$ & & & & & & & -0.05 & 0.07 & -1.04 \\
\hline Domination & & & & & & & 0.08 & 0.06 & 1.59 \\
\hline $\begin{array}{l}\text { Anti- } \\
\text { Environmental }\end{array}$ & & & & & & & 0.37 & 0.06 & $6.76^{* * *}$ \\
\hline $\mathrm{F}$ & & $8.65^{* * *}$ & & & $7.04^{* * *}$ & & & $18.33^{* * *}$ & \\
\hline$\Delta \mathrm{F}$ & & 0.04 & & & 0.05 & & & 0.22 & \\
\hline $\mathrm{R}^{2}$ & & 0.04 & & & 0.04 & & & 0.21 & \\
\hline $\mathrm{R}_{\text {adj. }}^{2}$ & & 0.04 & & & 0.01 & & & 0.17 & \\
\hline $\mathrm{R}^{2}$ change & & $2 ; 399$ & & & $3 ; 398$ & & & $6 ; 395$ & \\
\hline $\mathrm{df}$ & & & & $3.71^{*}$ & & & $28.17^{* * *}$ & \\
\hline
\end{tabular}

Notes: ${ }^{*} \mathrm{p}<0.05,{ }^{* *} \mathrm{p}<0.01,{ }^{* * *} \mathrm{p}<0.001$ 
Women's core attitudes about yellow-sticker shopping: Overall, the t-test (see Table 8) confirms that there is a significantly more positive feeling about yellow-sticker shopping than a negative evaluation of it. Overall quality assessments of yellow-sticker food are significantly higher than any other measure of women's evaluations of yellow-sticker food, suggesting that generally speaking, women see it as being high quality.

\section{Table 8. Paired $t$-test results}

\begin{tabular}{|l|c|c|l|c|c|}
\hline \multicolumn{1}{|c|}{ Variable 1 } & Mean & SD & \multicolumn{1}{c|}{ Variable 2 } & t value & p value \\
\hline Attributes & 3.46 & 0.71 & Suitability & 1.05 & 0.30 \\
\hline & 3.50 & 0.77 & Overall Quality & -2.26 & 0.02 \\
\hline & 2.49 & 0.96 & Negative Evaluation & 15.13 & 0.00 \\
\hline Suitability & 3.42 & 0.48 & Overall Quality & -1.94 & 0.05 \\
\hline & & & Negative Evaluation & 18.65 & 0.00 \\
\hline Overall Quality & & & Negative Evaluation & 15.21 & 0.00 \\
\hline
\end{tabular}

\subsection{RQ3: Factors Explaining Women's Reduced-Price Food Shopping Habits}

While it is useful to understand how women view food that is reduced in price, better understanding their reduced-price shopping habits also provides insight into the squander cycle. Overall, the data suggest that both socioeconomic factors and values significantly influence how women define their approach to reduced-price food shopping.

Strategic reduced-price shopper: The strategic reduced-price shopper (see Table 2) hunts for good bargains, often going to multiple grocery stores. Six variables were significantly correlated with the strategic reduced-price shopper: age $(\mathrm{r}=-0.16, \mathrm{p}<0.01)$, number of people living in the household $(\mathrm{r}=0.21, \mathrm{p}<0.01)$, value of social responsibility $(\mathrm{r}=-0.12$, $\mathrm{p}<0.05)$, positive affect for environmentally friendly shopping $(\mathrm{r}=.14, \mathrm{p}<.01)$, value of domination $(r=0.23, p<0.01)$, as well as anti-environmental attitudes $(r=0.35, p<0.01)$. The data suggest (see Table 9) that household demographics and values influence whether women are likely to identify with being a strategic reduced-price shopper. Women who live in larger households are more likely to be strategic reduced-price shoppers. Though age and social responsibility were significantly correlated with this shopper profile, they were not significant predictors in the regression model. Interestingly, both women who value environmentalism and identify as being anti-environmental, equally identify with being strategic reduced-price shoppers. Likewise, those women who value domination are also more likely to identify with this shopping strategy. Women's values are the most important predictors of identification with this shopping strategy. Overall, these factors account for an important 19 percent of the variance.

Table 9. Regression model for food shopper type: strategic reduced-price shopper

\begin{tabular}{|l|c|c|c|c|c|c|c|c|c|}
\hline \multicolumn{1}{|c|}{ Regressor } & Beta & $\begin{array}{c}\text { Model 1 } \\
\text { SE }\end{array}$ & $\mathbf{t}$ & Beta & $\begin{array}{c}\text { Model 2 } \\
\text { SE }\end{array}$ & $\mathbf{t}$ & Beta & $\begin{array}{c}\text { Model 3 } \\
\text { SE }\end{array}$ & $\mathbf{t}$ \\
\hline Intercept & & 0.18 & 18.92 & & 0.25 & 11.58 & & 0.47 & 1.71 \\
\hline Age & -0.16 & 0.05 & $-3.28^{* * *}$ & -0.11 & 0.05 & $-2.09^{*}$ & -0.06 & 0.04 & -1.31 \\
\hline
\end{tabular}




\begin{tabular}{|l|l|l|l|l|l|l|l|l|l|}
\hline $\begin{array}{l}\text { N Living in } \\
\text { Household }\end{array}$ & & & & 0.17 & 0.04 & $3.32^{* * *}$ & 0.11 & 0.04 & $2.27^{*}$ \\
\hline $\begin{array}{l}\text { Social } \\
\text { Responsibility }\end{array}$ & & & & & & & -0.06 & 0.08 & -1.14 \\
\hline $\begin{array}{l}\text { Pos. Affect } \\
\text { Env. Friendly } \\
\text { Shopping }\end{array}$ & & & & & & & & & \\
\hline Domination & & & & & & & 0.11 & 0.07 & $2.18^{*}$ \\
\hline $\begin{array}{l}\text { Anti- } \\
\text { Environmental }\end{array}$ & & & & & & & 0.31 & 0.06 & $5.64^{* * *}$ \\
\hline $\mathrm{F}$ & $10.77^{* * *}$ & & & $11.05^{* * *}$ & & & $16.76^{* * *}$ & \\
\hline$\Delta \mathrm{F}$ & $10.77^{* * *}$ & & & 11.05 & & & $18.64^{* * *}$ & \\
\hline $\mathrm{R}^{2}$ & 0.03 & & & 0.05 & & & 0.20 & \\
\hline $\mathrm{R}^{2}$ adj. & & 0.02 & & & 0.05 & & & 0.19 & \\
\hline $\mathrm{R}^{2}$ change & & 0.03 & & & 0.03 & & & 0.15 & \\
\hline $\mathrm{df}$ & & $1 ; 400$ & & & $2 ; 399$ & & & $6 ; 395$ & \\
\hline
\end{tabular}

Notes: ${ }^{*} \mathrm{p}<0.05,{ }^{* *} \mathrm{p}<0.01,{ }^{* * *} \mathrm{p}<0.001$

Value shopper: The value shopper (see Table 2) is focused on reducing food waste within their household, relies on frozen versus fresh food, and looks for the best value for money spent. Eight variables were significantly correlated with the value shopper: age $(\mathrm{r}=-0.22, \mathrm{p}<0.01)$, number of people living in the household $(r=0.21, p<0.01)$, education $(r=0.11, p<0.05)$, employment $(\mathrm{r}=0.11, \mathrm{p}<0.05)$, value of social responsibility $(\mathrm{r}=0.10, \mathrm{p}<0.05)$, positive affect for environmentally friendly shopping $(\mathrm{r}=0.16, \mathrm{p}<0.01)$, value of domination $(\mathrm{r}=0.20, \mathrm{p}<0.01)$, as well as antienvironmental attitudes $(\mathrm{r}=0.23, \mathrm{p}<0.01)$. The data found (see Table 10) personal demographics, household demographics, and values all significantly predicted women's identification with being "value shoppers". Women who are younger and live in larger households are more likely to identify with this kind of shopper profile. As with the strategic reduced-price shopper profile, women with both pro- and anti-environmental attitudes identify with being a value shopper as do women who value social responsibility.

Table 10. Regression model for food shopper type: value shopper

\begin{tabular}{|l|c|c|c|c|c|c|c|c|c|}
\hline \multicolumn{1}{|c|}{ Regressor } & Beta & $\begin{array}{c}\text { Model 1 } \\
\text { SE }\end{array}$ & $\mathbf{t}$ & Beta & $\begin{array}{c}\text { Model } \\
\text { 2 SE }\end{array}$ & $\mathbf{t}$ & Beta & $\begin{array}{c}\text { Model 3 } \\
\text { SE }\end{array}$ & $\mathbf{t}$ \\
\hline Intercept & & 0.17 & 21.45 & & 0.20 & 15.99 & & 0.33 & 4.44 \\
\hline Age & -0.21 & 0.03 & $-4.16^{* * *}$ & -0.16 & 0.03 & $-3.00^{* *}$ & -0.13 & 0.03 & $-2.55^{* *}$ \\
\hline Education & 0.08 & 0.03 & 1.51 & 0.08 & 0.03 & 1.64 & 0.09 & 0.03 & 1.89 \\
\hline Employment & 0.04 & 0.02 & 0.83 & 0.05 & 0.02 & 0.91 & 0.02 & 0.02 & 0.47 \\
\hline $\begin{array}{l}\text { N Living in } \\
\text { Household }\end{array}$ & & & & 0.16 & 0.03 & $3.06^{* *}$ & 0.11 & 0.03 & $2.29^{*}$ \\
\hline $\begin{array}{l}\text { Social } \\
\text { Responsibility }\end{array}$ & & & & & & & 0.17 & 0.05 & $3.16^{* *}$ \\
\hline
\end{tabular}




\begin{tabular}{|c|c|c|c|c|c|}
\hline $\begin{array}{l}\text { Pos. Affect Env. } \\
\text { Friendly } \\
\text { Shopping }\end{array}$ & & & 0.16 & 0.05 & $3.18^{* *}$ \\
\hline Domination & & & 0.07 & 0.04 & 1.33 \\
\hline $\begin{array}{l}\text { Anti- } \\
\text { Environmental }\end{array}$ & & & 0.27 & 0.04 & $4.90^{* * *}$ \\
\hline $\mathrm{F}$ & $8.31^{\text {*** }}$ & $8.70^{* * *}$ & & $10.80^{* * *}$ & \\
\hline$\Delta \mathrm{F}$ & $8.31^{\text {*** }}$ & $9.35^{* *}$ & & $11.95^{* * *}$ & \\
\hline $\mathrm{R}^{2}$ & 0.06 & 0.08 & & 0.18 & \\
\hline $\mathrm{R}_{\text {adj. }}^{2}$ & 0.05 & 0.07 & & 0.16 & \\
\hline $\mathrm{R}^{2}$ change & 0.06 & 0.02 & & 0.10 & \\
\hline $\mathrm{df}$ & $3 ; 398$ & $4 ; 397$ & & $8 ; 393$ & \\
\hline
\end{tabular}

Notes: ${ }^{*} \mathrm{p}<0.05,{ }^{* *} \mathrm{p}<0.01,{ }^{* * *} \mathrm{p}<0.001$

Minimising food waste shopper: The shopper who prioritises minimising food waste (see Table 2 ) is often a shopping browser who focuses their food consumption priorities on using shortdated food to avoid spoilage. Four variables were significantly correlated with the shopper who minimises food waste: monthly grocery spend $(\mathrm{r}=0.12, \mathrm{p}<0.05)$, value of social responsibility $(\mathrm{r}=0.38, \mathrm{p}<0.01)$, value of environmentally friendly buying $(\mathrm{r}=0.34, \mathrm{p}<0.01)$, and anti-environmental attitudes $(\mathrm{r}=-0.14, \mathrm{p}<0.01)$. The data (see Table 11$)$ suggest that the more that women spend on food each month, the more likely they were to adopt a shopping strategy to minimise food waste. Likewise, women with values of social responsibility and environmentally friendly shopping were also more likely to identify with this shopping strategy. Though anti-environmental attitudes were correlated, they did not predict the strategy in the regression model. Overall, the data account for 19 percent of the variance.

Table 11. Regression model for food shopper type: minimising food waste

\begin{tabular}{|l|c|c|c|c|c|c|}
\hline \multicolumn{1}{|c|}{ Regressor } & Beta & $\begin{array}{c}\text { Model 1 } \\
\text { SE }\end{array}$ & t & Beta & $\begin{array}{c}\text { Model 2 } \\
\text { SE }\end{array}$ & t \\
\hline Intercept & & 0.06 & 63.16 & & 0.26 & 7.10 \\
\hline Monthly Spend on Food Shopping & 0.12 & 0.00 & $2.33^{*}$ & 0.11 & 0.00 & $2.32^{*}$ \\
\hline Social Responsibility & & & & 0.30 & 0.05 & $5.71^{* * *}$ \\
\hline $\begin{array}{l}\text { Positive Affect Environmentally } \\
\text { Friendly Shopping }\end{array}$ & & & & 0.24 & 0.04 & $4.98^{* * *}$ \\
\hline Anti-Environmental & & & & 0.04 & 0.04 & 0.70 \\
\hline $\mathrm{F}$ & & $5.44^{*}$ & & & $24.63^{* * *}$ & \\
\hline$\Delta \mathrm{F}$ & & $5.44^{*}$ & & & $30.62^{* * *}$ & \\
\hline $\mathrm{R}^{2}$ & & 0.01 & & & 0.20 & \\
\hline $\mathrm{R}_{\text {adj. }}^{2}$ & & 0.01 & & & 0.19 & \\
\hline $\mathrm{R}^{2}$ change & & 0.01 & & & 0.19 & \\
\hline $\mathrm{df}$ & & $1 ; 395$ & & & $4 ; 392$ & \\
\hline
\end{tabular}

Notes: ${ }^{*} \mathrm{p}<0.05,{ }^{* *} \mathrm{p}<0.01,{ }^{* * *} \mathrm{p}<0.001$ 
Yellow-sticker target shopper: The yellow-sticker target shopper's strategy with food shopping focuses on the best locations to buy price-reduced food (see Table 2). Five variables were significantly correlated with yellow-sticker target shoppers: age $(r=-0.15, \mathrm{p}<0.01)$, number of people in the household $(\mathrm{r}=0.18, \mathrm{p}<0.01)$, positive affect for environmentally-friendly shopping $(\mathrm{r}=0.23, \mathrm{p}<0.01)$, value of domination $(\mathrm{r}=0.20, \mathrm{p}<0.01)$, and anti-environmental attitudes $(\mathrm{r}=0.21, \mathrm{p}<0.01)$. The data suggest (see Table 12) that household demographics and values influence women's identification with yellow-sticker target shopping. While age was significantly correlated, it was not a significant predictor in the regression model. However, the larger their household, the more likely women were to identify with being a yellow-sticker target shopper. The data indicate that women who are both pro- and anti-environmentally focused are likely to identify with being yellow-sticker target shoppers, but also those who value domination. Together, these results account for approximately 15 percent of the variance in identification with this food shopping strategy.

Table 12. Regression model for food shopper type: yellow-sticker target shopper

\begin{tabular}{|c|c|c|c|c|c|c|c|c|c|}
\hline Regressor & Beta & \begin{tabular}{|c|} 
Model 1 \\
SE \\
\end{tabular} & $\mathbf{t}$ & Beta & \begin{tabular}{|c|} 
Model 2 \\
SE \\
\end{tabular} & $t$ & Beta & $\begin{array}{c}\text { Model } 3 \\
\text { SE }\end{array}$ & $\mathrm{t}$ \\
\hline Intercept & & 0.18 & 20.11 & & 0.25 & 12.72 & & 0.40 & 2.11 \\
\hline Age & -0.15 & 0.05 & $-3.12^{* *}$ & -0.11 & 0.05 & $-2.07^{*}$ & -0.08 & 0.05 & -1.61 \\
\hline $\begin{array}{l}\text { N Living in } \\
\text { Household }\end{array}$ & & & & 0.15 & 0.04 & $2.87^{* *}$ & 0.10 & 0.04 & $2.04^{*}$ \\
\hline $\begin{array}{l}\text { Pos. Affect Env. } \\
\text { Friendly } \\
\text { Shopping }\end{array}$ & & & & & & & 0.27 & 0.07 & $5.73^{* * *}$ \\
\hline Domination & & & & & & & 0.11 & 0.07 & $2.21^{*}$ \\
\hline $\begin{array}{l}\text { Anti- } \\
\text { Environmental }\end{array}$ & & & & & & & 0.20 & 0.06 & $3.98^{* * *}$ \\
\hline $\mathrm{F}$ & & $9.72^{* *}$ & & & $9.06^{* * *}$ & & & $14.64^{* * *}$ & \\
\hline$\Delta \mathrm{F}$ & & $9.72^{* *}$ & & & $8.22^{* *}$ & & & $17.60^{* * *}$ & \\
\hline $\mathrm{R}^{2}$ & & 0.02 & & & 0.04 & & & 0.16 & \\
\hline $\mathrm{R}^{2}$ adj. & & 0.02 & & & 0.04 & & & 0.15 & \\
\hline $\mathrm{R}^{2}$ change & & 0.02 & & & 0.02 & & & 0.11 & \\
\hline $\mathrm{df}$ & & $1 ; 400$ & & & $2 ; 399$ & & & $5 ; 396$ & \\
\hline
\end{tabular}

Notes: ${ }^{*} \mathrm{p}<0.05,{ }^{* *} \mathrm{p}<0.01,{ }^{* * *} \mathrm{p}<0.001$

Impulse sale shopper: The impulse sale shopper is likely to buy food items they would not ordinarily buy because they are price-reduced, typically browsing for sales, or what they perceive as good deals. Four variables were significantly correlated with impulse sale shoppers: age $(r=-0.20$, $\mathrm{p}<0.01)$, number of people in the household $(\mathrm{r}=0.13, \mathrm{p}<0.05)$, value of domination $(\mathrm{r}=0.21$, $\mathrm{p}<0.01)$, and anti-environmental attitudes $(\mathrm{r}=0.23, \mathrm{p}<0.01)$. The data suggest (see Table 13$)$ that both individual factors and values predict whether women will identify with being impulse sale shoppers. Women who are younger, seek control and are anti-environmental are more likely to be impulse sale shoppers. This accounts for nine percent of the variance in impulse sale shopping. 
Table 13. Regression model for food shopper type: impulse sale shopper

\begin{tabular}{|l|c|c|c|c|c|c|c|c|c|}
\hline \multicolumn{1}{|c|}{ Regressor } & Beta & $\begin{array}{c}\text { Model 1 } \\
\text { SE }\end{array}$ & $\mathbf{t}$ & Beta & $\begin{array}{c}\text { Model } \\
\text { 2 SE }\end{array}$ & $\mathbf{t}$ & Beta & $\begin{array}{c}\text { Model 3 } \\
\text { SE }\end{array}$ & $\mathbf{t}$ \\
\hline Intercept & & 0.15 & 25.32 & & 0.21 & 17.36 & & 0.28 & 9.94 \\
\hline Age & -0.20 & 0.04 & $-4.10^{* * *}$ & -0.18 & 0.04 & $-3.43^{* * *}$ & -0.14 & 0.04 & $-2.67^{* *}$ \\
\hline $\begin{array}{l}\text { N Living in } \\
\text { Household }\end{array}$ & & & & 0.08 & 0.03 & 1.45 & 0.04 & 0.03 & 0.84 \\
\hline Domination & & & & & & & 0.12 & 0.06 & $2.39^{*}$ \\
\hline $\begin{array}{l}\text { Anti- } \\
\text { Environmental }\end{array}$ & & & & & & & 0.16 & 0.05 & $3.15^{* *}$ \\
\hline $\mathrm{F}$ & & $16.80^{* * *}$ & & & $9.47^{* * *}$ & & & $10.41^{* * *}$ & \\
\hline$\Delta \mathrm{F}$ & & 0.04 & & & 0.05 & & & 0.10 & \\
\hline $\mathrm{R}^{2}$ & & 0.04 & & & 0.04 & & & 0.09 & \\
\hline $\mathrm{R}^{2}{ }_{\text {adj. }}$ & & 0.04 & & & 0.01 & & & 0.05 & \\
\hline $\mathrm{R}^{2}$ change & & $1 ; 400$ & & & $2 ; 399$ & & & $4 ; 397$ & \\
\hline $\mathrm{df}$ & & & & 2.10 & & & $10.88^{* * *}$ & \\
\hline
\end{tabular}

Notes: ${ }^{*} \mathrm{p}<0.05,{ }^{* *} \mathrm{p}<0.01,{ }^{* * *} \mathrm{p}<0.001$

Differences in women's overall identification with food shopping profiles: Overall, the data suggest that women identify most with food shopping strategies that minimise food waste and least with the strategic reduced price shopping strategy. More importantly, the data also confirm that women value food economy overall (see Table 14).

Table 14. Paired $t$-test results shopper profile differences

\begin{tabular}{|l|c|c|l|c|c|}
\hline \multicolumn{1}{|c|}{ Variable 1 } & Mean & SD & \multicolumn{1}{|c|}{ Variable 2 } & t value & p value \\
\hline $\begin{array}{l}\text { Strategic Reduced-Price } \\
\text { Shopper }\end{array}$ & 2.83 & 1.01 & Value Shopper & -9.13 & 0.00 \\
\hline & 3.86 & 0.67 & $\begin{array}{l}\text { Minimising Food Waste } \\
\text { Shopper }\end{array}$ & -18.42 & 0.00 \\
\hline & 3.09 & 1.02 & Yellow-Sticker Shopper & -7.61 & 0.00 \\
\hline & 3.28 & 0.88 & Impulse Sale Shopper & -9.22 & 0.00 \\
\hline Value Shopper & 3.29 & 0.66 & $\begin{array}{l}\text { Minimising Food Waste } \\
\text { Shopper }\end{array}$ & -14.88 & 0.00 \\
\hline & & & Yellow-Sticker Shopper & 4.02 & 0.00 \\
\hline $\begin{array}{l}\text { Minimising Food Waste } \\
\text { Shopper }\end{array}$ & & & Impulse Sale Shopper & -0.25 & 0.80 \\
\hline & & & Impulse Sale Shopper & 13.25 & 0.00 \\
\hline Yellow-Ticket Shopper & & & Impulse Sale Shopper & -4.46 & 0.00 \\
\hline
\end{tabular}




\subsection{RQ4: Factors Influencing Women's Perceptions of Food Waste}

As we layer the complexity of women's approaches to the squander cycle, the final element in understanding this initial exploration of the cycle is to look closer at those factors influencing women's perceptions of food waste. The data demonstrate that socioeconomics and values both influence perceptions of food waste.

Overall propensity for food waste: Initially, we asked British women about the likelihood of wasting food in their household (see Table 2). Seven variables were significantly correlated with women's perception of food waste in their households: age $(r=-0.34$, $\mathrm{p}<0.01)$, income $(\mathrm{r}=0.14, \mathrm{p}<0.01)$, number of people in the household $(\mathrm{r}=0.32, \mathrm{p}<0.01)$, employment $(r=0.19, p<0.01)$, value of social responsibility $(r=-0.25, p<0.01)$, value of domination $(\mathrm{r}=0.29, \mathrm{p}<0.01)$, and anti-environmental attitudes $(\mathrm{r}=0.57, \mathrm{p}<0.01)$. The data suggest (see Table 15) that individual demographics, household demographics, and values all influence women's perception of their household's propensity to waste food each month accounting for a meaningful 41 percent of the total variance. Specifically, younger women, with more stable employment, living in larger households, believe their household is significantly more likely to waste food. Moreover, women who value domination and anti-environmentalism are also more likely to believe their household wastes food.

Table 15. Regression model for overall perception of propensity for food waste

\begin{tabular}{|l|c|c|c|c|c|c|c|c|c|}
\hline \multicolumn{1}{|c|}{ Regressor } & Beta & $\begin{array}{c}\text { Model 1 } \\
\text { SE }\end{array}$ & $\mathbf{t}$ & Beta & $\begin{array}{c}\text { Model } \\
\text { 2 SE }\end{array}$ & $\mathbf{t}$ & Beta & $\begin{array}{c}\text { Model 3 } \\
\text { SE }\end{array}$ & $\mathbf{t}$ \\
\hline Intercept & & 0.19 & 18.24 & & 0.23 & 11.81 & & 0.34 & 4.63 \\
\hline Age & -0.31 & 0.04 & $-6.54^{* * *}$ & -0.23 & 0.04 & $-4.74^{* * *}$ & -0.17 & 0.03 & $-3.99^{* * *}$ \\
\hline Employment & 0.13 & 0.03 & $2.68^{* *}$ & 0.13 & 0.03 & $2.59^{* *}$ & 0.09 & 0.02 & $2.24^{*}$ \\
\hline $\begin{array}{l}\text { Household } \\
\text { Income }\end{array}$ & & & & 0.03 & 0.02 & 0.51 & 0.03 & 0.02 & 0.61 \\
\hline $\begin{array}{l}\text { N Living in } \\
\text { Household }\end{array}$ & & & & 0.24 & 0.03 & $5.00^{* * *}$ & 0.17 & 0.03 & $4.13^{* * *}$ \\
\hline $\begin{array}{l}\text { Social } \\
\text { Responsibility }\end{array}$ & & & & & & -0.04 & 0.05 & -0.82 \\
\hline Domination & & & & & & & 0.08 & 0.05 & $2.01^{*}$ \\
\hline $\begin{array}{l}\text { Anti- } \\
\text { Environmental }\end{array}$ & & $29.49^{* * *}$ & & & & $22.41^{* * *}$ & & $41.38^{* * *}$ & \\
\hline $\mathrm{F}$ & & $29.49^{* * *}$ & & & & $13.48^{* * *}$ & & $54.57^{* * *}$ & \\
\hline$\Delta \mathrm{F}$ & & 0.13 & & & & 0.18 & & 0.42 & \\
\hline $\mathrm{R}^{2}$ & & 0.12 & & & & 0.18 & & 0.41 & \\
\hline $\mathrm{R}_{\text {adj. }}^{2}$ & & 0.13 & & & & 0.06 & & 0.24 & \\
\hline $\mathrm{R}^{2}$ change & $2 ; 399$ & & & & $4 ; 397$ & & $7 ; 394$ & \\
\hline $\mathrm{df}$ & & & & & & & \\
\hline
\end{tabular}

Notes: ${ }^{*} \mathrm{p}<0.05,{ }^{* *} \mathrm{p}<0.01,{ }^{* * *} \mathrm{p}<0.001$ 
Desire to avoid food waste: Women were also asked about the value they placed on avoiding food waste (see Table 2 ). Three variables were significantly correlated with the value that they placed on avoiding food waste: age $(r=0.13, \mathrm{p}<0.05)$, value of social responsibility $(\mathrm{r}=0.14$, $\mathrm{p}<0.01)$, and positive affect of being an environmentally friendly shopper $(\mathrm{r}=0.31, \mathrm{p}<0.01)$. The data suggest (see Table 16) that older women who value being environmentally friendly food shoppers are more likely to believe it is important to avoid food waste. Though social responsibility was significantly correlated with avoiding food waste, it was not a significant predictor in the regression equation. These two predictive variables account for 10 percent of the variance.

Table 16. Regression model for value on avoiding food waste

\begin{tabular}{|c|c|c|c|c|c|c|}
\hline Regressor & Beta & Model 1 SE & $\mathbf{t}$ & Beta & Model 2 SE & $\mathbf{t}$ \\
\hline Intercept & & 0.16 & 19.52 & & 0.29 & 5.94 \\
\hline Age & 0.13 & 0.04 & $2.59^{* *}$ & 0.11 & 0.04 & $2.40^{*}$ \\
\hline Social Responsibility & & & & 0.02 & 0.06 & 0.32 \\
\hline $\begin{array}{l}\text { Value on Being an } \\
\text { Environmentally } \\
\text { Friendly Shopper }\end{array}$ & & & & 0.30 & 0.06 & $5.93^{* * *}$ \\
\hline $\mathrm{F}$ & & $6.69^{* *}$ & & & $16.36^{* * *}$ & \\
\hline$\Delta \mathrm{F}$ & & $6.69^{* *}$ & & & $20.86^{* * *}$ & \\
\hline $\mathrm{R}^{2}$ & & 0.02 & & & 0.11 & \\
\hline $\mathrm{R}^{2}{ }_{\text {adj. }}$ & & 0.01 & & & 0.10 & \\
\hline $\mathrm{R}^{2}$ change & & 0.02 & & & 0.09 & \\
\hline $\mathrm{df}$ & & $1 ; 400$ & & & $3 ; 398$ & \\
\hline
\end{tabular}

Notes: ${ }^{*} \mathrm{p}<0.05,{ }^{* *} \mathrm{p}<0.01,{ }^{* * *} \mathrm{p}<0.001$

Guilt over food waste: Another way to explore food waste is to identify the factors that affect guilt over food waste (see Table 2). Five variables were significantly correlated with food waste guilt: age $(r=-0.25, \mathrm{p}<0.01)$, number of people in the household $(\mathrm{r}=0.16, \mathrm{p}<0.01)$, positive affect towards being an environmentally friendly shopper $(\mathrm{r}=0.33, \mathrm{p}<0.01)$, value of domination $(\mathrm{r}=0.26, \mathrm{p}<0.01)$, and anti-environmental attitudes $(\mathrm{r}=0.22, \mathrm{p}<0.01)$. The data find (see Table 17) that age and values significantly predict the likelihood of feeling guilt at their own food waste habits. Though the number of people living in the household was significantly correlated, it was not a significant predictor for guilt over food waste in the regression model. However, domination, as well as pro- and anti-environmental values, were also significant, accounting for 20 percent of the variance on their own.

Table 17. Regression model for guilt over food waste

\begin{tabular}{|l|c|c|c|c|c|c|c|c|c|}
\hline Regressor & Beta & $\begin{array}{c}\text { Model 1 } \\
\text { SE }\end{array}$ & $\mathbf{t}$ & Beta & $\begin{array}{c}\text { Model 2 } \\
\text { SE }\end{array}$ & $\mathbf{t}$ & Beta & $\begin{array}{c}\text { Model } \\
\text { 3 SE }\end{array}$ & $\mathbf{t}$ \\
\hline Intercept & & 0.17 & 23.36 & & 0.23 & 15.76 & & 0.35 & 2.11 \\
\hline Age & -0.25 & 0.04 & $-5.05^{* * *}$ & -0.22 & 0.04 & $-4.24^{* * *}$ & -0.19 & 0.04 & $-4.02^{* * *}$ \\
\hline
\end{tabular}




\begin{tabular}{|l|c|c|c|c|c|c|c|c|c|}
\hline $\begin{array}{l}\text { N Living in } \\
\text { Household }\end{array}$ & & & & 0.09 & 0.04 & 1.75 & 0.03 & 0.03 & 0.68 \\
\hline $\begin{array}{l}\text { Value Env. } \\
\text { Friendly Shop }\end{array}$ & & & & & & & 0.38 & 0.06 & $8.61^{* * *}$ \\
\hline Domination & & & & & & & 0.16 & 0.06 & $3.39^{* * *}$ \\
\hline $\begin{array}{l}\text { Anti- } \\
\text { Environmental }\end{array}$ & & & & & & & 0.22 & 0.05 & $4.64^{* * *}$ \\
\hline $\mathrm{F}$ & & $25.52^{* * *}$ & & & $14.36^{* * *}$ & & & & $28.46^{* * *}$ \\
\hline$\Delta \mathrm{F}$ & $25.52^{* * *}$ & & & 3.06 & & & & $35.38^{* * *}$ \\
\hline $\mathrm{R}^{2}$ & & 0.06 & & & 0.07 & & & & 0.26 \\
\hline $\mathrm{R}_{\text {adj. }}^{2}$ & & 0.06 & & & 0.06 & & & & 0.26 \\
\hline $\mathrm{R}^{2}$ change & & 0.06 & & & 0.01 & & & & 0.20 \\
\hline $\mathrm{df}$ & & $1 ; 400$ & & & $2 ; 399$ & & & & $5 ; 396$ \\
\hline
\end{tabular}

Notes: ${ }^{*} \mathrm{p}<0.05,{ }^{* *} \mathrm{p}<0.01,{ }^{* * *} \mathrm{p}<0.001$

Food wasted in women's households: Finally, because previous behaviours tend to influence future behaviours, we asked women to identify the percentage of food wasted in their household, and to identify if there were factors influencing this as a way to better answer RQ4. Six variables were significantly correlated to estimated percentages of food wasted in women's households: age $(\mathrm{r}=-0.26, \mathrm{p}<0.01)$, number of people in the household $(\mathrm{r}=0.18, \mathrm{p}<0.01)$, employment $(\mathrm{r}=0.10$, $\mathrm{p}<0.05)$, value of social responsibility $(\mathrm{r}=-0.30, \mathrm{p}<0.01)$, value of domination $(\mathrm{r}=0.26, \mathrm{p}<0.01)$, and anti-environmental attitudes $(\mathrm{r}=0.49, \mathrm{p}<0.01)$. The data suggest (see Table 18) that individual demographics and values significantly predict women's estimated amount of food that is wasted in their households each month. While employment and the number of people living in the household were significantly correlated, they were not significant predictors in this regression model. However, younger women were significantly more likely to waste more food. Likewise, women who have social responsibility, domination, and anti-environmental values also report wasting more food each month.

Table 18. Regression model for estimated \% of food wasted in household

\begin{tabular}{|l|c|c|c|c|c|c|c|c|c|}
\hline \multicolumn{1}{|c|}{ Regressor } & Beta & $\begin{array}{c}\text { Model 1 } \\
\text { SE }\end{array}$ & $\mathbf{t}$ & Beta & $\begin{array}{c}\text { Model 2 } \\
\text { SE }\end{array}$ & $\mathbf{t}$ & Beta & $\begin{array}{c}\text { Model 3 } \\
\text { SE }\end{array}$ & $\mathbf{t}$ \\
\hline Intercept & & 4.91 & 7.32 & & 6.12 & 4.50 & & 9.35 & 1.51 \\
\hline Age & -0.25 & 0.96 & $-4.99^{* * *}$ & -0.21 & 1.00 & $-4.03^{* * *}$ & -0.15 & 0.89 & $-3.23^{* * *}$ \\
\hline Employment & 0.05 & 0.68 & 1.06 & 0.06 & 0.68 & 1.15 & 0.02 & 0.60 & 0.54 \\
\hline $\begin{array}{l}\text { N Living in } \\
\text { Household }\end{array}$ & & & & 0.12 & 0.84 & $2.28^{*}$ & 0.05 & 0.75 & 1.13 \\
\hline $\begin{array}{l}\text { Social } \\
\text { Responsibility }\end{array}$ & & & & & & & -0.14 & 1.46 & $-2.87^{* *}$ \\
\hline Domination & & & & & & & 0.11 & 1.34 & $2.42^{*}$ \\
\hline $\begin{array}{l}\text { Anti- } \\
\text { Environmental }\end{array}$ & & & & & & & 0.36 & 1.20 & $6.96^{* * *}$ \\
\hline
\end{tabular}




\begin{tabular}{|l|c|c|l|l|c|l|l|l|l|}
\hline $\mathrm{F}$ & & $14.61^{* * *}$ & & & $11.57^{* * *}$ & & & $27.57^{* * *}$ & \\
\hline$\Delta \mathrm{F}$ & & $14.61^{* * *}$ & & & $5.18^{*}$ & & & $10.15^{* * *}$ & \\
\hline $\mathrm{R}^{2}$ & & 0.07 & & & 0.08 & & & 0.30 & \\
\hline $\mathrm{R}^{2}{ }_{\text {adj. }}$ & & 0.06 & & & 0.07 & & & 0.28 & \\
\hline $\mathrm{R}^{2}$ change & & 0.07 & & & 0.01 & & & 0.22 & \\
\hline $\mathrm{df}$ & & $2 ; 399$ & & & $3 ; 398$ & & & $6 ; 395$ & \\
\hline
\end{tabular}

Notes: ${ }^{*} \mathrm{p}<0.05,{ }^{* *} \mathrm{p}<0.01,{ }^{* * *} \mathrm{p}<0.001$

\section{DISCUSSION AND CONCLUSIONS}

There are two narratives emerging from these findings. The first is that values are strongly connected to the evaluation of yellow-sticker shopping, price-reduced shopping habits, and perceptions of food waste. In most cases, these findings suggest that the more that women are interested in being socially responsible and environmentally conscious, the more likely they are to construct price-reduced shopping within the perception of themselves as socially responsible agents. This social responsibility narrative is supported when we consider the findings that those women who strongly associate with values of social responsibility and environmentalism also report more concern for food waste and across all measures of behavioural intention regarding food waste by demonstrating a significantly lower propensity for waste than women who adhere to anti-environmental values.

The challenge with this narrative that women are sustainability-minded in their routine life decisions is that, in the exploration of price-reduced shopping habits, women who described themselves as pro-environmental and anti-environmental in their value systems were equally likely to report the same price-reduced shopping habits. On the surface, this creates a problem in the assumption that pro-social values are driving women's decision-making with regard to sustainability in everyday decisions. In fact, it seems to suggest that instead of environmental and social concerns driving behavioural intention, it may be a way that women rationalise their routine choices after the fact. In essence, women may use socially responsible and sustainable explanations for choices that are more pragmatically driven to make themselves feel better about their behaviours. In short, women may rationalise their shopping habits as being sustainable as a way to demonstrate a socially desirable identity.

The second clear narrative that emerges from the data is that British women who come from a lower socioeconomic status (SES) have a significantly more negative view of yellow-sticker shopping, reduced-price shopping habits, and ironically report being more likely to waste food despite being less able to afford to be wasteful. This does not mean that they were less likely to buy price-reduced food or adopt price-reduced shopping strategies; rather that their emotional affect towards the behaviours was negative. Whereas women from higher SES backgrounds tend to rationalise their decisions about food economy in the context of choice and agency to be socially responsible and 
environmentally friendly, women from lower SES backgrounds view price-reduced food shopping as compulsory and express frustration or negative affect because of the lack of agency to make different choices or even rationalise their choices differently.

The duality of women's economics in food shopping seems to suggest that whether women feel connected to issues of sustainability and environmentalism has more to do with their perception of control and agency in making routine decisions than the actual decisions that they are likely to make - at least early in the squander sequence at the preacquisition and acquisition stages. From a strategic perspective then, one of the ways to engage women from lower SES backgrounds is to help them develop a narrative of control over their own decision-making. Instead of emphasizing mental scripts that reinforce the economic deprivation they are experiencing, connecting them with choices they can make to support their families and improve the environment may be able to improve their perceived control and empower them within their communities for action. Given the differences between women's and men's perspectives on price-reduced shopping, this notion of agency may more uniquely benefit women from lower SES positions to make better decisions at the consumption and disposition stages of the squander sequence (see Figure 1).

The data suggest that while women from different SES backgrounds may have different attitudes at the preacquisition and acquisition stages, women's shopping behaviours and even their shopping profiles are not significantly different. Women may be better engaged as sustainable actors if their perceptions of their own agency in decision-making are improved in these first two stages. Aside from using routine activities such as food shopping as a vehicle for women's empowerment, which is a valuable end in itself, the data also suggest that improving perceptions of women's agency at these first two stages could have a meaningful impact on improving food security within the UK and potentially globally as well.

RQ4 explored a number of perceptions of food waste finding that women who were younger, from a lower SES, and who held anti-environmental views consistently reported being more likely to waste food in their households. The irony is that these women are most vulnerable to food insecurity in the UK. Since the data also found that perceived control over what people can and want to eat in their own households drives the reported propensity to waste food, targeting women's agency to improve their own lives and their families lives through price-reduced and yellow-sticker shopping might help reduce the squander sequence within the UK, and improve the likelihood that women from all backgrounds would more strongly identify with the importance of sustainability and environmental protection.

This study's central aim was to better understand the ways in which women recognise and implement sustainable actions. What we found instead was that in their everyday lives most women are making similar consumer-based choices regarding sustainability in their food choices. However, the way they understand or rationalise their choices is significantly different and their own agency or perceived control is what seems to be driving women's attitudes towards sustainability and environmentalism. From both an 
ecofeminist and feminist economics perspective, if women are able to perceive themselves as agents in their own lives they may be more willing to view themselves as agents of sustainability and environmental protection, despite their relative levels of economic deprivation. This is also likely to have onward effects in terms of the larger squander sequence with regard to food waste.

Yet these findings also demonstrate that environmental and sustainability movements are also likely to be less credible with women in lower SES categories because they do not believe they have the same food purchasing options as women in higher SES categories. Women from lower SES backgrounds are seemingly less likely to identify with sustainability and environmental values - even to the point of being hostile towards them - because they believe that they have no ability to influence sustainability. More than that, they seem to resent the choices they feel they must make (e.g. price-reduced shopping) because they do not have economic agency. As the risks of food insecurity grows with changes to the climate, regional and global economic changes, and growing rich-poor gaps within countries, the negative association between causes seemingly championed by the privileged may make it more difficult to not only engage women from less privileged backgrounds but these negative attitudes may represent a barrier to their own empowerment.

This study represents an important step in developing verifiable data to investigate social critique. Though these findings present additional problems that need to be investigated with regard to the duality of privilege, women's experiences, attitudes towards sustainability, and the squander sequence, they also provide a theoretically and research-driven path forward in exploring how the squander sequence can be affected at the preacquisition and acquisition stages that will also improve women's agency and empowerment overall.

\section{REFERENCES}

Adams, C. J. (2007). Ecofeminism and the Sacred. London: Continuum.

Albelda, R. (2011). Time Binds: US Antipoverty Policies, Poverty, and the Well-Being of Single Mothers. Feminist Economics, 17(4): 189-214.

Alcock, I. (2012). Measuring Commitment to Environmental Sustainability: The Development of a Valid and Reliable Measure. Methodological Innovations Online, 7(2): 13-26.

Aschemann-Witzel, J., Gimenez, A. and Ares, G. (2018a). Consumer In-Store Choice of Suboptimal Food to Avoid Food Waste: The Role of Food Category, Communication and Perception of Quality Dimensions. Food Quality and Preference, 68: 29-39.

Aschemann-Witzel, J., Gimenez, A. and Ares, G. (2018b). Convenience or Price Orientation? Consumer Characteristics Influencing Food Waste Behaviour in the Context of an Emerging Country and the Impact on Future Sustainability of the Global Food Sector. Global Environmental Change, 49: 85-94. 
Aschemann-Witzel, J., Jensen, J. H., Jensen, M. H. and Kulikovskaja, V. (2017). Consumer Behaviour Towards Price-Reduced Suboptimal Foods in the Supermarket and the Relation to Food Waste in Households. Appetite, 116: 246-258.

Barcena-Martin, E. and Moro-Egido, A. I. (2013). Gender and Poverty Risk in Europe. Feminist Economics, 19(2): 69-99.

Bardasi, E. and Gornick, J. (2008). Working for Less? Women's Part-Time Wage Penalties Across Countries. Feminist Economics, 14(1): 37-72.

Besthorn, F. H. and Pearson McMillen, D. (2002). The Oppression of Women and Nature: Ecofeminism as a Framework for an Expanded Ecological Social Work. Families in Society: The Journal of Contemporary Human Services, 83(3): 221-232.

Block, L. G., Keller, P. A., Vallen, B., Williamson, S., Birau, M. M., Grinstein, A., Haws, K. L., LaBarge, M. C., Lamberton, C., Moore, E. S., Moscato, E. M., Walker Reczek, R. and Tangari, A. H. (2016). The Squander Sequence: Understanding Food Waste at Each Stage of the Consumer Decision-Making Process. Journal of Public Policy \& Marketing, 35(2): 292-304.

Buckingham, S. (2004). Ecofeminism in the Twenty-First Century. The Geographical Journal, 170(2): 146-154.

Buzov, I. (2007). Socijalna perspektiva ekofeminizma. Socijalna ekologija, 16(1): 1-16.

Cantillon, S. and Nolan, B. (2001). Poverty Within Households: Measuring Gender

Differences Using Nonmonetary Indicators. Feminist Economics, 7(1): 5-23.

Carson, R. (1962). Silent Spring. New York, NY: Houghton Mifflin.

Cifrić, I. (1990). Ekološka adaptacija i socijalna pobuna. Zagreb: Radničke novine.

Corman, S. R. (2000). The Need for Common Ground. In: Corman, S. R. and Poole, M. S. (eds.), Perspectives on Organizational Communication: Finding Common Ground (pp. 3-13). New York, NY: The Guilford Press.

Corsi, M., Botti, F. and D'Ippoliti, C. (2016). The Gendered Nature of Poverty in the EU: Individualized Versus Collective Poverty Measures. Feminist Economics, 22(4): $82-100$.

Dangour, A. (2018). Women in Agriculture are Key to Boosting Food Security. Farmer's Weekly, 2018(18023): 6-7.

D'Eaubonne, F. (1990). What Could an Eco-Feminist Society Be? From: Liberty, Equality and Women? Anthology, (Hartmann). URL: http://richardtwine.com/ ecofem/deaubonne.pdf (11 Nov 2018).

De Groot, J. I. and Steg, L. (2008). Value Orientations to Explain Beliefs Related to Environmental Significant Behavior: How to Measure Egoistic, Altruistic, and Biospheric Value Orientations. Environment and Behavior, 40(3): 330-354.

De Hooge, I. E., Oostindjer, M., Aschemann-Witzel, J., Normann, A., Loose, S. M. and Almli, V. A. (2017). This Apple is too Ugly for Me!: Consumer Preferences for Suboptimal Food Products in the Supermarket and at Home. Food Quality and Preference, 56: 80-92.

Dimitropolous, S. (2018). Women Against Climate Change. Womankind, 18: 76-84. Emel, J. (1995). Are You Man Enough, Big and Bad Enough? Ecofeminism and Wolf Eradication in the USA. Environment and Planning: Society and Space, 13(6): 707734. 
Fukuda-Parr, S. (1999). What Does Feminization of Poverty Mean? It Isn't just Lack of Income. Feminist Economics, 5(2): 99-103.

Galić, B. and Geiger, M. (2007). Od logike dominacije prema etici brižnosti: Konceptualna utemeljenja ekofeminizma. Socijalna ekologija, 16(1): 17-33.

Galić, B. and Geiger, M. (2006). Valorizacija ženskog: Rodni aspekti odnosa spram okoliša. Socijalna ekologija, 15(4): 339-355.

Garcia, A. S. and Wanner, T. (2017). Gender Inequality and Food Security: Lessons from the Gender-Responsive Work of the International Food Policy Research Institute and the Bill and Melinda Gates Foundation. Food Security, 9(5): 1091-1103.

Gaard, G. (2011). Ecofeminism Revisited: Rejecting Essentialism and Re-Placing Species in a Material Feminist Environmentalism. Feminist Formations, 23(2): 26-53.

Gaard, G. (2010). New Directions for Ecofeminism: Toward a More Feminist Ecocriticism. Interdisciplinary Studies in Literature and Environment, 17(4): 643-665.

Geiger Zeman, M. and Holy, M. (2014). "Kako to nije zaživjelo? Zašto to nije zanimljivo?" - snaga i obećanje ekofeminizma u Hrvatskoj. Ekonomska i ekohistorija, 10(1): 94-112.

Graham-Rowe, E., Jessop, D. C. and Sparks, P. (2014). Identifying Motivations and Barriers to Minimising Household Food Waste. Resources, Conservation and Recycling, 84: 15-23.

Graham-Rowe, E., Jessop, D. C. and Sparks, P. (2015). Predicting Household Food Waste Reduction Using an Extended Theory of Planned Behaviour. Resources, Conservation and Recycling, 101: 194-202.

Himmelweit, S. (2002). Making Visible the Hidden Economy: The Case for GenderImpact Analysis of Economic Policy. Feminist Economics, 8(1): 49-70.

Hooks, B. (2000). Feminist Theory: From Margin to Center. London: Pluto Press.

Holy, M. (2007). Mitski aspekti ekofeminizma. Zagreb: TIM Press.

Hozić, A. and True, J. (2017). Brexit as a Scandal: Gender and Global Trumpism. Review of International Political Economy, 24(2): 270-287.

Iversen, V. (2003). Intra-Household Inequality: A Challenge for the Capability Approach? Feminist Economics, 9(2-3): 93-115.

John, D. P. (1988). Ecofeminism. Ecospirit, 3(2): 1-10. URL: http://home.moravian. edu/public/relig/ecospirit/issues/vol3no2.pdf. (11 Nov 2018).

Kasearu, K., Maestripieri, L. and Ranci, C. (2017). Women at Risk: The Impact of Labour-Market Participation, Education and Household Structure on the Economic vulnerability of Women Through Europe. European Societies, 19(2): 202-221.

Kelsey, S., Morris, C. and Crewe, L. (2018). Yellow-Sticker Shopping as Competent, Creative Consumption. Area, 51(1): 64-71.

Kirn, A. (1998). Nekoliko temeljnih dilema ekološke etike. Socijalna ekologija, 11(3): 257-270.

King, Y. (1989). The Ecology of Feminism and the Feminism of Ecology. In: Plant, J. (ed.), Healing the Wounds: The Promise of Ecofeminism (pp. 18-28). Philadelphia, PA: New Society Publishers. 
MacGregor, S. (2004). From Care to Citizenship: Calling Ecofeminism back to Politics. Ethics and the Environment, 9(1): 56-84.

McKay, A., Campbell, J., Thomson, E. and Ross, S. (2013). Economic Recession and Recovery in the UK: What's Gender Got to Do with It? Feminist Economics, 19(3): $108-123$.

Miller, K. I. (2000). Common Ground from the Post-Positivist Perspective. In: Corman, S. R. and Poole, M. S. (eds.), Perspectives on Organizational Communication: Finding Common Ground (pp. 46-67). New York, NY: The Guilford Press.

Office of National Statistics (2018). Household Disposable Income and Inequality in the UK: Financial Year Ending 2017. URL: https://www.ons.gov.uk/peoplepopulationandcommunity/personalandhouseholdfinances/incomeandwealth/bulletins/ householddisposableincomeandinequality/financialyearending2017 (7 Dec 2018).

Parfitt, J., Barthel, M. and Macnaughton, S. (2010). Food Waste Within Food Supply Chains: Quantification and Potential for Change to 2050. Philosophical Transactions of the Royal Society of London B: Biological Sciences, 365(1554): 3065-3081.

Pearson, R. and Elson, D. (2015). Transcending the Impact of the Financial Crisis in the United Kingdom: Towards Plan F - A Feminist Economic Strategy. Feminist Review, 109(1): 8-30.

Perkins, E., Kuiper, E., Quiroga-Martinez, R., Turner, T. E., Brownhill, L. S., Mellor, M., Todorova, Z., Jochimsen, M. A. and McMahon, M. (2005). Introduction: Exploring Feminist Ecological Economics / Gender, Development, and Sustainability from a Latin American Perspective / African Peasants and Global Gendered Class Struggle for the Commons / Ecofeminist Political Economy: Integrating Feminist Economics and Ecological Economics / Habits of Thought, Agency, and Transformation: An Institutional Approach to Feminist Ecological Economics / The Network Vorsorgendes Wirtschaften / Engendering Organic Farming. Feminist Economics, 11(3): 107-150.

Puleo, A. H. (2017). What is Ecofeminism? Quaderns de la Mediterrania, 25: 27-34.

Plumwood, V. (1994). The Ecopolitics Debate and the Politics of Nature. In: Warren, J. K. (ed.), Ecological Feminism (pp. 64-87). New York, NY: Routledge.

Plumwood, V. (1986). Ecofeminism: An Overview and Discussion of Positions and Arguments. Australasian Journal of Philosophy, 64(1): 120-138.

Reeves, A., Loopstra, R. and Stuckler, D. (2017). The Growing Disconnect Between Food Prices and Wages in Europe: Cross-National Analysis of Food Deprivation and Welfare Regimes in Twenty-One EU Countries, 2004-2012. Public Health Nutrition, 20(8): 1414-1422.

Salleh, A. (1992). The Ecofeminism / Deep Ecology Debate: A Reply to Patriarchal Reason. Environmental Ethics, 14(3): 195-216.

Social Mobility Commission (2019). Social mobility in Great Britain - State of the Nation 2018 to 2019. URL: https:/www.gov.uk/government/publications/social-mobility-in-great-britain-state-of-the-nation-2018-to-2019 (9 Jun 2020).

Spretnak, C. (1990). Ecofeminism: Our Roots and Flowering. In: Diamond, I. and 
Feman Orenstein, G. (eds.), Reweaving the World (pp. 3-14). San Francisco, CA: Sierra Club Books.

Statista (2020). Annual Population Growth in the United Kingdom in 2020, by Region. URL: https://www.statista.com/statistics/294681/population-england-united-kingdom-uk-regional/ (21 Aug 2020).

Topić, M. (2020). Ekofeministička analiza vrijednosti i filozofija globalnih eko-selâ: Jesu li žene sklonije kolektivizmu i anti-hijerarhiji nego muškaraci? In: Đurđević, G. and Suzana Marjanić (eds.), Ekofeminizam: Od zelenih do ženskih studija. Zagreb: Durieux.

Topić, M. and Tench, R. (2016). The Corporate Social Responsibility in Lidl's Communication Campaigns in Croatia and the UK. The Qualitative Report, 21(2): 351376.

Warren, T. (2006). Moving Beyond the Gender Wealth Gap: On Gender, Class, Ethnicity, and Wealth Inequalities in the United Kingdom. Feminist Economics, 12(12): 195-219.

Warren, K. J. (2000). Ecofeminist Philosophy: A Western Perspective on what It is and why It Matters (Studies in Social, Political, and Legal Philosophy). New York, NY: Rowman and Littlefield.

Wheelock, J., Oughton, E. and Baines, S. (2003). Getting By with a Little Help from Your Family: Toward a Policy-Relevant Model of the Household. Feminist Economics, 9(1): 19-45.

Wilson, R. (2018). Employment Rate Rises to 75.6\%. Ri Magazine, 15 May 2018. URL: https://www.recruitment-international.co.uk/blog/2018/05/employmentrate-rises-to-75-dot-6-percent (7 Dec 2018). 


\title{
ŽENE I RASIPANJE HRANE U UJEDINJENOM KRALJEVSTVU: EKOFEMINISTIČKA I FEMINISTIČKA EKNOMSKA ANALIZA
}

\author{
Martina Topić, Audra Diers Lawson i Sarah Kelsey
}

\begin{abstract}
Sažetak
Ovaj rad analizira medupovezanost roda, klase, sigurnosti opskrbe hranom, održivog odnosa prema otpadu od hrane i vrijednosti. Pri tome povezujemo feminističku ekonomiju sekofeminizmom kako bismo kontekstualizirali kupnju namirnica u Ujedinjenom Kraljevstvu. Hrana kao otpad ekološko je i ekonomsko pitanje, te danas predstavlja globalnu prijetnju, pri čemu razvijene države najznačanije doprinose svakoj fazi "rasipanja hrane“ (engl. "squander cycle") kao resursa. Ovakva nam analiza istodobno omogućuje propitivanje feminističke ekonomije, kao i bolje razumijevanje procesa donošenja odluka o kupnji, smještajući ih u širi kontekst sustava vrijednosti, koji povezujemo is raspravama o održivom razvoju i zaštiti okoliša. U prikupljenju podataka korištena je metoda online ankete u trajanju od 20-ak minuta, provedena na kupljenom uzorku populacije Ujedinjenog Kraljevstva putem sustava „Smart Survey“. Analizirano je N=792 potpuno ispunjenih anketa. Rezultati istraživanja ukazuju na postojanje dvojnog narativa o kupnji namirnica. Žene kupnju namirnica na sniženju ocjenjuju kao društveno odgovorno i okolišno orijentirano ponašanje. Međutim, žene iz nižih socioekonomskih slojeva iskazuju zadršku i negativno ocjenjuju namirnice po sniženoj cijeni. Shodno tome, zaključujemo da ove razlike u stavovima reflektiraju razlike u relativnoj percepciji individualnog djelovanja i kontrole, za koje podaci pokazuju da su povezani s većom sklonosti prema stvaranju otpada od hrane i njezinog rasipanja.
\end{abstract}

Ključne riječi: žene, ekofeminizam, feministička ekonomija, kupovina na sniženju, rasipanje hrane, Ujedinjeno Kraljevstvo

\section{FRAUEN UND VERSCHWENDUNG VON LEBENSMITTELN IM VEREINIGTEN KÖNIGSREICH VON GROßBRITANNIEN UND NORDIRLAND: ÖKOFEMINISTISCHE UND FEMINISTISCHE WIRTSCHAFTSANALYSE}

\author{
Martina Topić, Audra Diers Lawson und Sarah Kelsey
}

\section{Zusammenfassung}

Diese Arbeit analysiert die gegenseitigen Verbindungen unter Geschlecht, Klasse, Sicherheit der Nahrungsmittelversorgung, nachhaltigem Essen und Werten. Dabei bringen wir feministische Wirtschaft mit dem Ökofeminismus in Verbindung, um den Einkauf von Lebensmitteln im VK zu kontextualisieren. Die Lebensmittelverschwendung iste eine sowohl ökologische als auch ökonomische Frage und sie stellt heute eine globale Drohung dar, wobei entwickelte Staaten am erheblichsten in jeder Phase der Verschwendung von Lebensmitteln als Ressourcen (engl. „squander sequence") beitragen. Eine solche Analyse ermöglicht uns gleichzeitig eine Infragestellung der feministischen Ökonomie, sowie ein besseres Verständnis des Prozesses der Entscheidungsfindung beim Einkaufen, indem sie im Kontext des Wertesystems in Verbindung mit Diskussionen über die nachhaltige Entwicklung und den Umweltschutz betrachtet werden. Bei der Sammlung von Daten wurde die Methode der Onlineumfrage von ca. 20 Minuten angewandt, am gekauften Muster der Population von VK mit Hilfe des Systems "Smart Survey“. Es wurden N=792 völlig ausgefüllte Umfragebogen analysiert. Die Forschungsergebnisse weisen auf zweierlei Schilderungen des Lebensmitteleinkaufs hin. Franen bewerten den Kauf von Lebensmitteln zum reduzierten Preis als sozialverantwortliches und umweltfreundliches Benehmen. Die Frauen aus neidrigeren sozialökonomischen Schichten jedoch zeigen sich reserviert und bewerten die reduzierten Lebensmittel negativ. Dementsprechend schließen wir, dass diese Unterschiede in Stellungnahmen die Unterschiede reflektieren in der verhältnismäßigen Wahrnehmung 
Soc. ekol. Zagreb, Vol. 30 (2021.), No. 2

Martina Topić et al: Women and the Squander Cycle in Food Waste (UK): An Ecofeminist and Economics Analysis

des individuellen Handelns und der Kontrolle, wofür die Daten zeigen, dass sie eher zur Lebensmittelverschwendung und zum Wegwerfen von Nahrungsmitteln geneigt sind.

Schlüsselwörter: Frauen, Ökofeminismus, feministische Wirtschaft, Einkäufe zum reduzierten Preis, Lebensmittelverschwendung, Vereinigtes Königsreich von Großbritannien und Nordirland 